\title{
COMPOSITE PARTICLES IN MUDSTONES: EXAMPLES FROM THE LATE CRETACEOUS TUNUNK SHALE MEMBER OF THE MANCOS SHALE FORMATION
}

\author{
ZHIYANG LI AND JUERGEN SCHIEBER \\ Department of Earth and Atmospheric Sciences, Indiana University, Bloomington, Indiana 47405, U.S.A.
}

\begin{abstract}
Despite recent advances in understanding the complex dynamics of mud deposition, it remains a challenging task to characterize the grain size, origin of different components, and sedimentary textures of mudstones through detailed petrographic analysis. In this study, the Tununk Shale in Utah has been examined by optical and scanning electron microscopy (SEM) to determine how variations in petrographic characteristics (e.g., composition, texture) of this shelf mudstone succession reflect changing depositional environments. In the context of the general depositional setting, detailed petrographic studies indicate that most mud in the Tununk system were transported in bedload as silt- to sand-size mud-dominated composite particles (MCPs), rather than specific components (e.g., clay minerals, silt grains, fossil fragments) of smaller size (micrometers to tens of micrometers). Three types of MCPs in the Tununk Shale can be identified and distinguished from each other. These include fecal pellets, altered volcanic rock fragments, and shale lithics. Two other types of MCPs, namely floccules and soft mud rip-up clasts, likely contributed significantly to the formation of the precursor mud matrix of the Tununk Shale. Due to their water-rich nature, however, floccules and mud rip-up clasts suffer significant compaction. Except in fortunate circumstances, they are therefore no longer discernible in the rock record.

MCPs and their role in the formation of fine-grained sedimentary successions has largely gone unnoticed in previous studies. The recognition criteria, as well as petrographic characteristics of each type of MCP in different depositional environments of the Tununk Shale, are summarized here, with the intent that they may benefit future studies of other mudstone successions. The complex variability in the characteristics of different types of MCPs illustrated in this case study, however, highlights the need for additional systematic petrographic studies (integrating both optical and SEM) in order to develop and refine the current recognition criteria of MCPs in fine-grained sedimentary rocks. Detailed petrographic examination of mudstones, though labor intensive, can yield critical information regarding their provenance and depositional setting, as well as provide general insights into the underlying causes for mudstone heterogeneity.
\end{abstract}

\section{INTRODUCTION}

Mudstones are fine-grained sedimentary rocks composed of $50 \%$ or more particles smaller than 62.5 micrometers (Potter et al. 2005; Lazar et al. 2015) and contain clay-size $(<3.9$ micrometers) and/or silt-size (3.962.5 micrometers) particles. Due to their small grain size, mudstones have historically been interpreted as deposited mainly through suspension fallout under mostly quiet conditions (Potter et al. 2005). However, recent advances in experimental studies (Schieber et al. 2007; Schieber and Southard 2009; Schieber 2011; Schieber et al. 2013; Yawar and Schieber 2017), observations of modern muddy shelf sedimentation (Rine and Ginsburg 1985; Nittrouer et al. 1986; Wright et al. 1988; Allison et al. 2000; Traykovski et al. 2000; Denommee et al. 2016), as well as a growing number of detailed facies studies of ancient mudstone successions (Macquaker and Gawthorpe 1993; Schieber 1999; Bhattacharya and MacEachern 2009; Plint et al. 2012; Plint 2014; Wilson and Schieber 2014; Harazim and McIlroy 2015; Li et al. 2015; Wilson and Schieber 2015; Schieber 2016a; Birgenheier et al. 2017; Knapp et al. 2017) have made the case for the important role of bedload transport in moving and depositing significant amounts of mud under relatively energetic conditions. The common presence of low-angle ripple laminae and localized erosional features in fine-grained sediments as revealed by laboratory, modern mud, and ancient rock studies, indicate that deposition of mud is mostly through traction currents that carry sediment across the seabed (Schieber et al. 2007; Macquaker and Bohacs 2007). The significant role of bedload transport was further reinforced by a number of detailed petrographic studies of both ancient and modern fine-grained deposits, which show that silt- to sand-size mud-dominated composite particles constitute a significant portion (sometimes $>50 \%$ ) of the overall rock volume (Plint et al. 2012; Plint 2014; Schieber 2016b; Laycock et al. 2017; Shchepetkina et al. 2018). Instead of mud accumulating via passive settling from suspension, the common presence of silt- to sand-size composite particles implies that a wide variety of hydrodynamic processes (e.g., turbidity currents, storm-induced bottom currents, tidal currents, etc.) are responsible for mud deposition and the formation of fine-grained sedimentary successions. If a distinction can be made between the grain size at deposition (potentially coarse) and the apparent grain size after compaction (fine on first approximation), any number of mudstones in the 
rock record may turn out to have been siltstones and sandstones in a hydraulic sense.

\section{Definition of "Mud-Dominated Composite Particle"}

In this study, the term mud-dominated composite particle (MCP) refers to particles that consist of multiple mineral grains and are dominated by clay- to silt-size minerals (regardless of mineralogy). MCPs in fine-grained sedimentary successions can have various origins and exhibit great variability in composition and texture. According to their origin, a wide range of terms have been used to describe these composite particles. For example, "floccules" are water-rich $(85 \%$ or more water content by volume) MCPs which consist dominantly of clay minerals with admixture of fine silt and organic debris and are held together by van der Waals forces (Kranck 1975; Lick et al. 1993; Schieber et al. 2007; Schieber and Southard 2009; Schieber 2011; Yawar and Schieber 2017). "Mud rip-up clasts" ("intraclasts") are produced by erosion of surficial muds and can have up to $85 \%$ water content depending on how deep erosion cuts down into the substrate (Macquaker and Gawthorpe 1993; Schieber et al. 2010). Another type of water-rich MCPs are "fecal pellets," which consists of a mixture of organic materials and sometimes clay and silt particles bound together in fecal matter of a variety of organisms (Hattin 1975; Minoura and Osaka 1992; Macquaker et al. 2010; Denommee et al. 2016). MCPs derived from fully lithified rocks, on the other hand, have much lower water contents and resist compaction. Possible origins of these MCPs can be "volcanic rock fragments" that have been variably altered during diagenesis (Zimmerle 1993, 1998), as well as recycled fragments of consolidated mudstones that are exposed on land or in coastal areas ("shale clast" or "shale lithics" in Schieber 2016b).

For the purpose of this study, the general term MCP is favored here because it allows inclusion of a range of composite particle types. Compared to other terms mentioned above, the term MCP is purely descriptive and implies only that each individual MCP is transported and deposited as a single grain.

\section{Objectives of This Study}

The presence of MCPs (e.g., siltstone rock fragments, shale lithics, etc.) is a commonly documented attribute of lithic sandstones (Ulmer-Scholle et al. 2015). In that context they are rather distinct when they are surrounded by translucent grains such as quartz and feldspar. Recognition of MCPs becomes increasingly difficult as grain size diminishes, a problem that is further exacerbated when the surrounding matrix is mud and particle contrast becomes minimal. MCPs derived from a wide range of origins have different implications regarding their provenance, sediment dispersal mechanisms, and diagenetic processes. Not recognizing them in the rock record can potentially lead to seriously flawed interpretations of ancient mudstone successions. However, only a small number of studies have looked into the presence of MCPs in ancient fine-grained deposits, and many uncertainties with respect to their types and origins still remain (Plint et al. 2012; Schieber and Bennett 2013; Plint 2014; Schieber 2016b; Laycock et al. 2017). More studies that attempt to differentiate diverse types of MCPs and improved ways to identify them in the rock record are clearly needed and are of critical importance for furthering our understanding of the essential causes of mudstone variability.

In support of that effort, the Upper Cretaceous Tununk Shale Member of the Mancos Shale Formation, exposed in south-central Utah, USA, was selected for a detailed case study of MCPs. Sedimentologic facies analysis indicates that the Tununk Shale was deposited as an offshore mud blanket in a relatively energetic environment, and that almost the entire Tununk succession was subject to bedload transport ( $\mathrm{Li}$ and Schieber 2018). Transport and deposition of MCPs appear to have played an important role in the formation of the Tununk succession, making it a good natural laboratory for characterizing MCPs through detailed petrographic analysis. Characteristics (e.g., dimension, mineral composition, texture, optical properties, etc.) of different types of MCPs, as well as their likely origins and dispersal mechanisms, are summarized, in order to improve our ability to recognize MCPs in fine-grained sedimentary rocks and to gain a petrographic perspective for the depositional boundary conditions of these rocks.

\section{GEOLOGICAL SETTING OF THE TUNUNK SHALE}

During the Late Jurassic and Cretaceous, the geology of western North America was controlled largely by the subduction of the Farallon plate beneath the North American plate (Livaccari 1991; DeCelles 2004). The compressive forces associated with plate convergence, combined with conductive heating initiated by subduction, led to crustal thickening in orogenic belts such as the Sevier fold-thrust belt (Livaccari 1991; DeCelles 2004). Subsidence due to flexural loading of the crust created an asymmetric foreland basin, bounded in the west by the rising Sevier orogenic belt and in the east by the stable North American craton (Fig. 1; Kauffman 1977, 1985; Kauffman and Caldwell 1993). During the Late Cretaceous, the foreland basin experienced active thrusting, subsidence, uplift (forebulge uplift), and extensive volcanism (DeCelles 2004; DeCelles and Coogan 2006; Yonkee and Weil 2015). A magmatic arc, comprising a belt of calc-alkaline intrusive and volcanic rocks, was located along the western margin of the North American continent (Fig. 1; Yonkee and Weil 2015).

Global greenhouse climate and elevated rates of sea-floor spreading persisted throughout the Cretaceous, resulting in a global eustatic highstand that caused repeated flooding of the foreland basin (Kauffman 1977, 1985; Kauffman and Caldwell 1993; Miller et al. 2005; Hay 2008; Haq 2014). In North America, the resulting epicontinental sea, termed the Western Interior Seaway (WIS), connected the Gulf of Mexico and the Northern Boreal Sea during peak eustatic highstand in middle early Turonian time (Fig. 1). This epeiric seaway never exceeded more than a few hundred meters water depth (Weimer 1984; Kauffman 1985; Sageman and Arthur 1994), but was up to $1,500 \mathrm{~km}$ wide (Fig. 1). In response to sediments supplied from the Sevier orogenic belt and volcanic highlands, the WIS was broadly characterized by high siliciclastic input and high sedimentation rates along the western margin, and little clastic input on the eastern margin (Kauffman 1977, 1985).

The Tununk Shale was deposited during the late Cenomanian to middle Turonian along the western margin of the Western Interior Seaway (WIS). A series of transgressive-regressive sequences, driven mainly by secondorder eustatic sea-level cycles, have been identified in the deposits of the foreland basin (Kauffman 1977, 1985). In southern Utah, in response to the Greenhorn transgressive-regressive sea-level cycle, offshore marine shale deposits of the Tununk Shale overlie coarser nonmarine and paralic deposits of the Dakota Sandstone and grade upward into shallow marine and deltaic sandstones of the Ferron Sandstone Member (Fig. 2). The paleoshoreline during deposition of the Tununk Shale generally trended northeast-southwest (Fig. 1; Zelt 1985; Leithold 1994).

\section{Depositional Framework of the Tununk Shale}

In outcrop, the Tununk Shale consists mainly of dark gray calcareous to noncalcareous mudstones with numerous thin silt- and sand-rich beds and volcanic ash beds (i.e., bentonites; Peterson et al. 1980; Zelt 1985). A series of regionally traceable bentonite beds have been used to correlate the Tununk Shale in south-central Utah (Henry Mountains Region) with its lateral equivalent, the Tropic Shale in southern Utah (Kaiparowits Plateau) (Zelt 1985; Leithold, 1994; T1-T17 in Fig. 2). Detailed characteristics of sedimentary facies and depositional environments of the Tununk Shale are discussed in a previous study ( $\mathrm{Li}$ and Schieber 2018), and are only briefly 

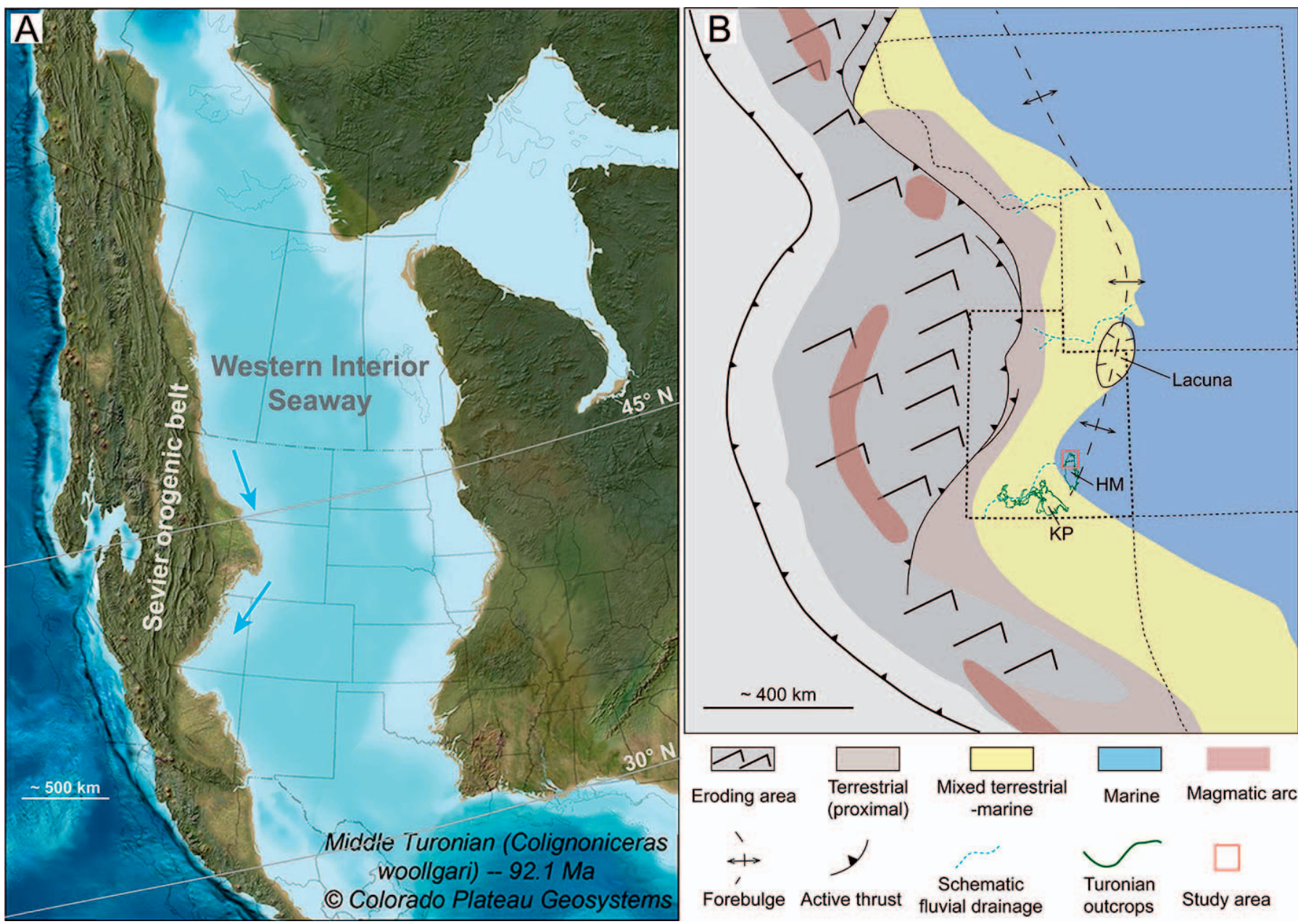

FIg. 1.-A) Middle Turonian paleogeographic map showing the extent of the Western Interior Seaway (Blakey 2014). Dominant southward-directed longshore currents along the western margin of the seaway are indicated by blue arrows. Paleolatitudes are from Sageman and Arthur (1994). B) Paleogeographic reconstruction of the foreland basin of middle North America that shows evolving topography (schematic), locations of active faults, general depositional environments, forebulge position during the Turonian, and location of the study area (modified from Yonkee and Weil 2015). The sediment supply of the Tununk Shale was derived from multiple sources, including clastic sediments derived from the Sevier orogenic belt and volcanic highlands to the west, primary productivity from the upper water column, wind-borne volcanic ash, and submarine erosion at the lacuna developed in northeastern Utah. The lacuna in northeastern Utah developed as a submarine unconformity from the late Cenomanian to middle Turonian due to uplift of an intra-basinal culmination (Ryer and Lovekin 1986). HM, Henry Mountains Region; KP, Kaiparowits Plateau.

summarized here. The Tununk Shale ranges in thickness from 170 to 210 $\mathrm{m}$ in the study area and is interpreted as an offshore mud blanket on a storm-dominated shelf. The sediment supply of the Tununk Shale was derived from multiple sources, including significant amounts of clastic sediments derived from the Sevier orogenic belt and volcanic highlands, primary productivity (e.g., foraminifera tests, fecal pellets, and coccoliths), wind-borne volcanic ash, and possibly from submarine erosion at the lacuna developed in northeastern Utah (Fig. 1). The Tununk Shale consists of a stack of four lithofacies packages that include, stratigraphically: 1) carbonate-bearing, silty and sandy mudstone (CSSM), 2) silt-bearing, calcareous mudstone (SCM), 3) carbonate-bearing, silty mudstone to muddy siltstone (CMS), and 4) noncalcareous, silty and sandy mudstone (SSM) (Fig. 3; Li and Schieber 2018). Upsection, the relative amount of the carbonate component in the Tununk Shale gradually increases from the CSSM to SCM facies, and then decreases to the CMS facies, and becomes absent in the SSM facies. Vertical variations in lithofacies types and sedimentary facies characteristics indicate that the depositional environments of the Tununk Shale shifted laterally from a distal middle-shelf to outer-shelf (CSSM to SCM facies), then from an outer-shelf to inner-shelf environment (SCM to CMS, and to SSM facies). These lateral shifts were controlled largely by the second-order Greenhorn transgressive-regressive sea-level cycle (Fig. 3). Storm-induced, shore-parallel geostrophic flow and offshore-directed flows likely were the dominant processes that governed the transport and deposition of mud across and along a storm-dominated shelf (Li and Schieber 2018).

\section{METHODOLOGY}

Samples for petrographic study were collected from three detailed stratigraphic sections of the Tununk Shale that were measured along a 30km-long transect near Hanksville (Fig. 4). This transect is oriented approximately parallel to the paleoshoreline (Fig. 4). Throughout each section, relatively unweathered samples were collected at an average spacing of $1 \mathrm{~m}$ (more closely spaced in some places). More than 500 samples, collected from all three measured sections, were taken back to the laboratory, embedded in epoxy, and slabbed and polished for examination of small-scale (mm- to cm-scale) sedimentary and biogenic features. Representative samples from all four lithofacies packages in the Tununk Shale (Fig. 3) were selected to evaluate compositional and textural 


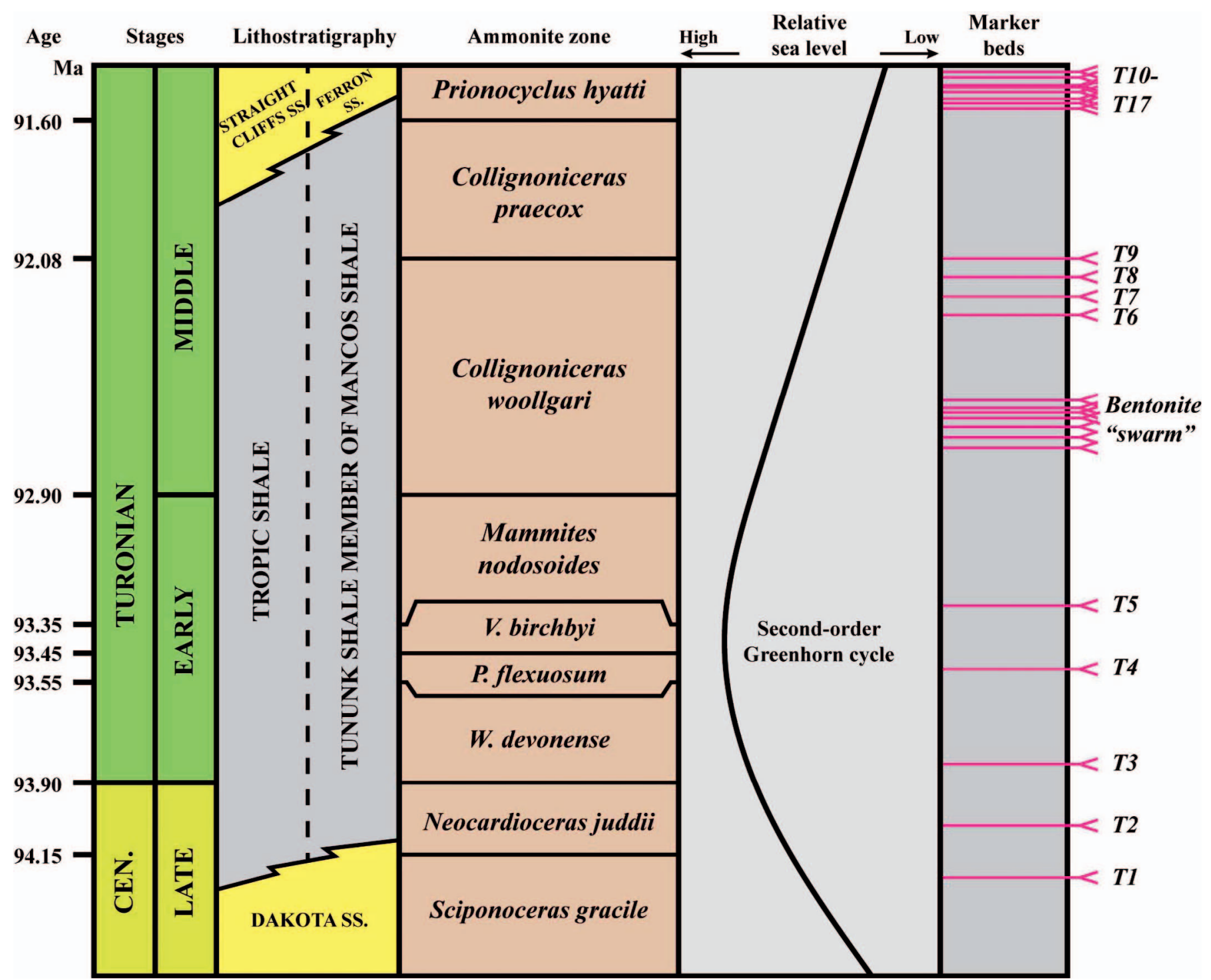

FIG. 2.-Lower to middle Turonian stratigraphy in southern Utah (compiled from Kauffman 1977; Zelt 1985; Leithold 1994; Leithold and Dean 1998). Absolute dates are from Ogg et al. (2012).

characteristics through petrographic analysis. A total of 41 polished thin sections (20-25 $\mu \mathrm{m}$ in thickness) and 48 ion-milled samples (up to $12 \mathrm{~mm}$ diameter) were prepared (Schieber 2013), in both bedding-normal and bedding-parallel orientations.

The adopted procedure for petrographic examination is summarized below. The initial focus was an examination of the overall petrographic composition and texture of different lithofacies types and identification of MCPs in the Tununk Shale. Detailed petrographic examination of polished thin sections and ion-milled samples were conducted using a petrographic microscope and an FEI Quanta 400 scanning electron microscope (SEM). The SEM was operated at $15 \mathrm{kV}$ and a working distance of $10 \mathrm{~mm}$. Energydispersive X-ray spectroscopy (EDS) was used to determine the composition and mineralogy of individual grains.

Having obtained a general understanding of the variability of MCPs in terms of their types and characteristics, 14 polished thin sections were selected to examine the characteristics of different types of MCPs through a combination of images taken from the same particles by optical microscopy and SEM. MCPs were first identified with a petrographic microscope, and their characteristics in both plane-polarized light (PPL) and cross-polarized light (CPL) were recorded, as well as their locations in the thin section. Following this, these same particles were then located with the SEM and further examined. Use of EDS and the higher SEM magnification allowed the recognition of different types of MCPs on the basis of texture and mineral composition. To avoid potential bias in MCP recognition, for some samples the sequence of observations was reversed. MCPs were first identified under the SEM, and then were located and examined under a petrographic microscope. Examinations of MCPs through combined optical microscopy and SEM imaging allows for consistent identification and characterization of different types of MCPs that occur in the Tununk Shale.

After the MCPs were identified, their interpreted outlines were manually traced on the SEM photomicrographs in Adobe Illustrator. Grain parameters (long-axis vs. minor-axis dimension) of all MCPs documented in SEM photomicrographs were measured with the image analysis software ImageJ. The abundances (volume by $2 \mathrm{D}$ area) of silt- to sand-size particles (also manually traced in Adobe Illustrator) and different types of MCPs were measured on five representative SEM photomicrographs (magnification around $\times 500$ ) from each lithofacies package using ImageJ. By 

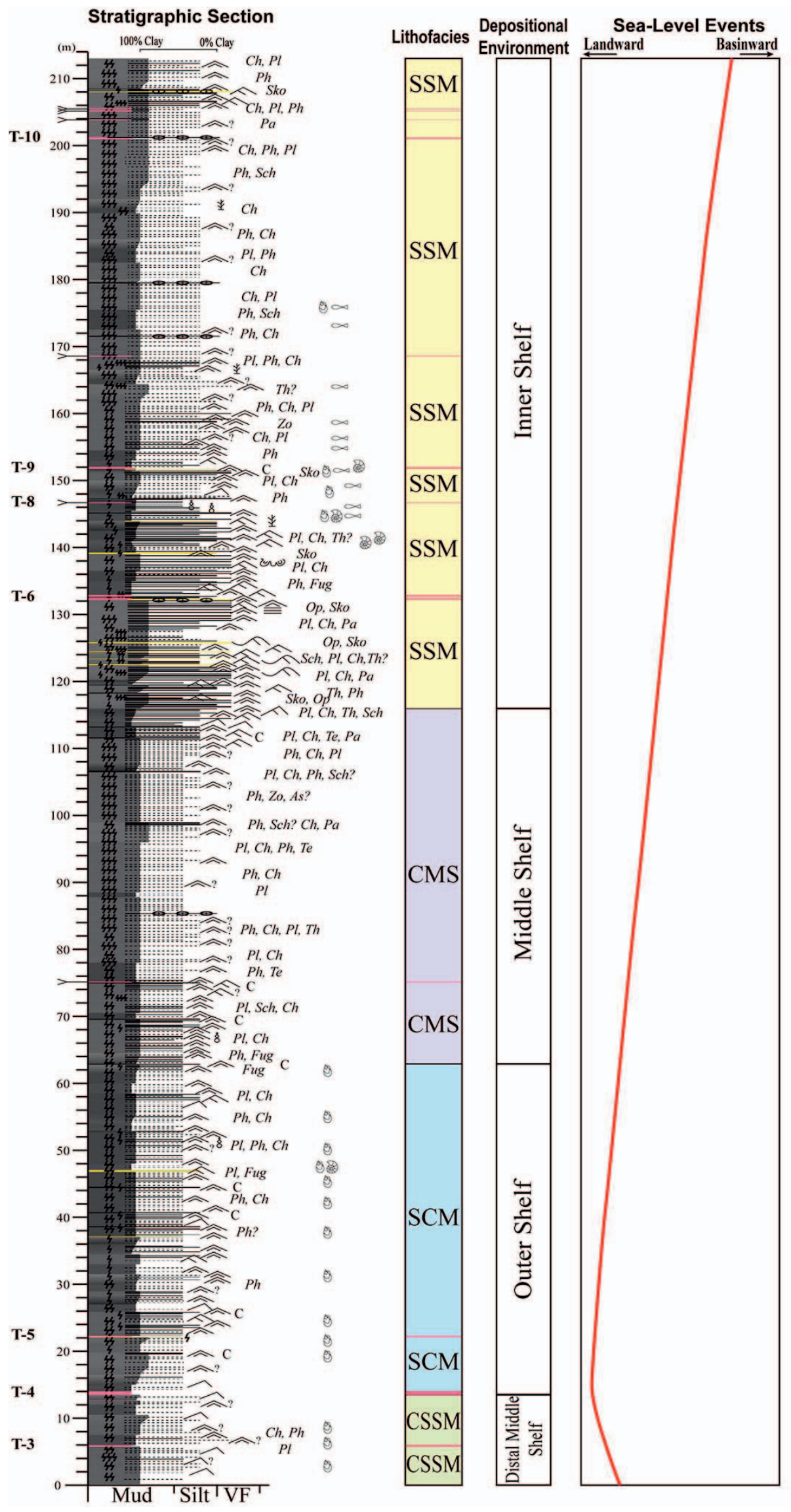

Sedimentary Structures

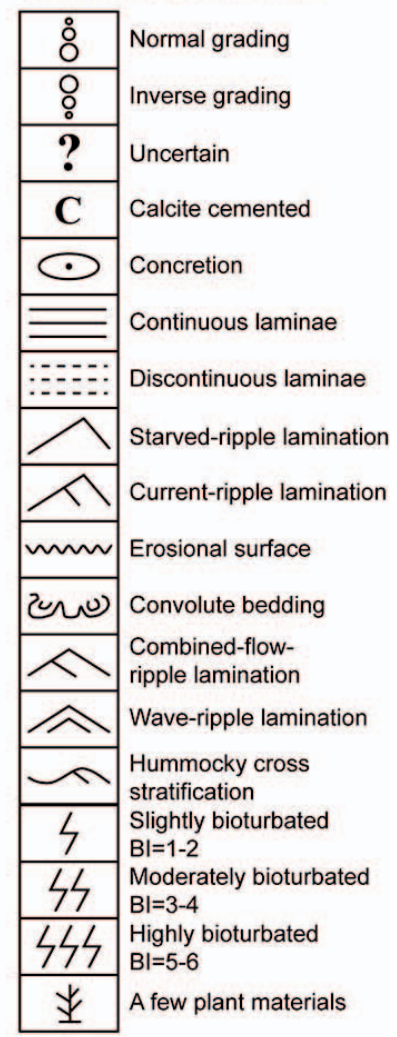

\begin{tabular}{ll}
\multicolumn{2}{c}{ Ichnofacies } \\
As & Asterosoma \\
$\mathrm{Ch}$ & Chondrites \\
$\mathrm{Cy}$ & Cylindrichnus \\
$\mathrm{Di}$ & Diplocraterion \\
$\mathrm{Op}$ & Ophiomorpha \\
$\mathrm{Pa}$ & Paleophycus \\
$\mathrm{Ph}$ & Phycosiphon \\
$\mathrm{PI}$ & Planolites \\
$\mathrm{Ro}$ & Rosselia \\
Sch & Schaubcylindrichnus \\
Sko & Skolithos \\
Te & Teichichnus \\
Th & Thalassinoides \\
Zo & Zoophycos
\end{tabular}

$\begin{array}{ll} & \text { Fossil Debris } \\ \text { Inoceramid bivalve } \\ \text { Ammonite } \\ \infty & \text { Fish debris }\end{array}$

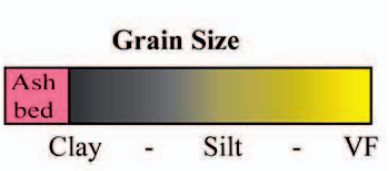




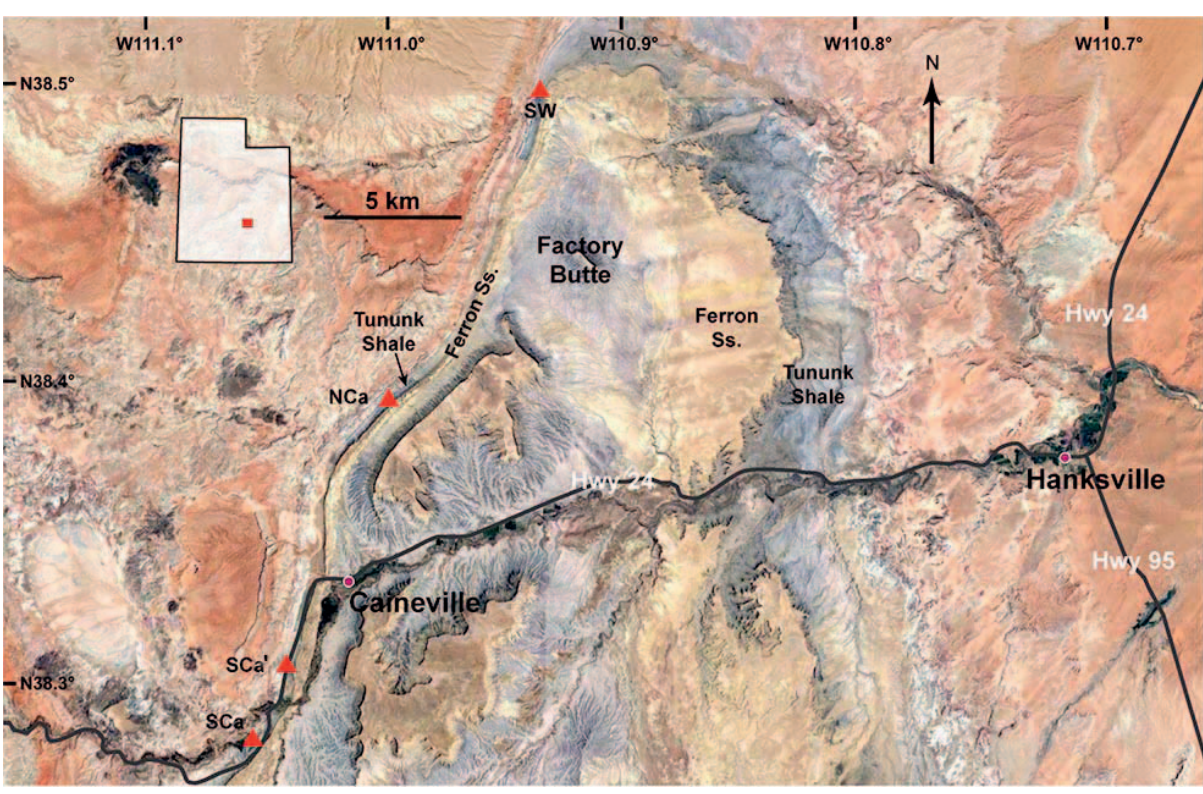

FIG. 4.-Map of the Tununk Shale outcrop belts near Hanksville. Red triangles indicate locations of three stratigraphic sections measured in this study (SW, Salt Wash; NCa, North Caineville; SCa, South Caineville). The section measured at $\mathrm{SCa}$ is a composite section consisting of two segments ( $\mathrm{SCa}$ and $\left.\mathrm{SCa}^{\prime}\right)$. comparing the results from the representatives with other SEM photomicrographs, the proportion of silt and sand present, as well as the proportion of different types of MCPs in each lithofacies package, can be estimated and semi-quantified.

\section{TYPES OF MUD-DOMINATED COMPOSITE PARTICLES AND THEIR ORIGINS}

Detailed petrographic examination of the Tununk Shale shows three distinct types of MCPs, including fecal pellets, volcanic rock fragments, and shale lithics, differentiated on the basis of mineral composition and textural contrast with the surrounding fine-grained matrix. Mud rip-up clasts are another type of MCP present in the Tununk Shale, but they can be recognized only under rare circumstances with sufficient compositional contrast.

Petrographic compositions of the framework grains (medium silt to sand grains with single mineralogy) and fine-grained matrix (mud-dominated, clay to fine silt size) of different lithofacies packages in the Tununk Shale are summarized in Table 1. The original depositional mineralogy of the Tununk Shale is largely preserved and has only been slightly influenced by early diagenesis during shallow burial (Nadeau and Reynolds 1981a; Sethi and Leithold 1994). The interpreted depositional environment of each lithofacies ( $\mathrm{Li}$ and Schieber 2018) is also listed in Table 1. Petrographic characteristics such as shape, mineral composition, texture, and optical properties of all four types of MCPs identified in the Tununk Shale are summarized in Table 2. Petrographic characteristics of different types of MCPs are illustrated using photomicrographs of the same particles taken in thin section and under the SEM (Appendix 1, see Supplemental Material). Information on the grain size and length/width ratio of different types of MCPs are summarized in Table 3. Grain-size distribution for each type of MCP is shown in Figure 5. Because almost all MCPs documented in this study range from medium silt to sand size (Fig. 5), the abundance of each type of MCP in different lithofacies packages is normalized to the silt and sand content and shown in Table 4.

\section{Fecal Pellets}

Fecal pellets are present in the lower three lithofacies types of the Tununk Shale (Fig. 3, Table 4) including the carbonate-bearing, silty and sandy mudstone, silt-bearing, calcareous mudstone, and carbonate-bearing, silty mudstone to muddy siltstone facies. Upsection, the abundance of fecal pellets shows a gradual increase from the carbonate-bearing, silty and sandy mudstone to the silt-bearing, calcareous mudstone facies, and then a gradual decrease to the carbonate-bearing, silty mudstone to muddy siltstone facies (Table 4). In polished slabs, fecal pellets give the rock a white-speckled appearance (Fig. 6). In some intervals fecal pellets are concentrated in laminae and show preferred orientation (Fig. 6A). In more bioturbated intervals fecal pellets are dispersed randomly, "floating" in the fine-grained matrix, and are thus less readily recognized in polished slabs (Fig. 6C). Most fecal pellets are oval and rather elongated (Table 2), a few hundred micrometers long, and several tens of micrometers wide (Table 3). Fecal pellets range from coarse silt to medium sand size in this study (Fig. $5)$.

In thin sections, fecal pellets tend to be light-colored (compared to the surrounding clay-rich matrix) and a little greenish or brownish (Table 2, Fig. 7). SEM examination indicates that most fecal pellets consist exclusively of coccoliths and coccolith debris (Fig. 8). Some fecal pellets are brown to dark brown in color due to a subordinate amount of amorphous organic matter and clay-mineral-like particles (Figs. 7E, 8).

\section{Origin of Fecal Pellets}

The fecal pellets identified in the Tununk Shale are identical to those documented from other Late Cretaceous deposits in the WIS (e.g., lower Blue Gate Member of the Mancos Shale in Utah, Bridge Creek Limestone Member in Colorado, Carlile Shale in Kansas; Hattin 1975; Sethi and Leithold 1994; Birgenheier et al. 2017). Their almost wholly coccolithic nature and absence of terrigenous detritus indicates that they were

FIG. 3.-A representative stratigraphic section of the Tununk Shale measured at Salt Wash, with general lithofacies packages and the second-order Greenhorn sea-level cycle. T3-T10 represent regionally continuous bentonite marker beds after Zelt (1985). The Tununk Shale consists of a stack of four lithofacies packages including: 1) carbonate-bearing, silty and sandy mudstone (CSSM), 2) silt-bearing, calcareous mudstone (SCM), 3) carbonate-bearing, silty mudstone to muddy siltstone (CMS), and 4) noncalcareous, silty and sandy mudstone (SSM). The same facies characteristics and lithofacies stacking patterns are also observed in the other measured sections (Supplemental Figure 1). See Li and Schieber (2018) for more details on sedimentary facies characteristics of each lithofacies package. 
TABLE 1.-Depositional settings and petrographic characteristics of four general lithofacies types in the Tununk Shale. The Tununk Shale consists of a stack of four lithofacies packages, including: 1) carbonate-bearing, silty and sandy mudstone (CSSM), 2) silt-bearing, calcareous mudstone (SCM), 3) carbonate-bearing, silty mudstone to muddy siltstone (CMS), and 4) noncalcareous, silty and sandy mudstone (SSM) (Li and Schieber, 2018). 1. Siliciclastic components include clays (dominant smectite, small amount of randomly interstratified illite-smectite, kaolinite, and chlorite), fine-silt-size grains such as quartz, feldspar, and mica. 2. Carbonate mud includes dominantly coccolith debris and minor amounts of small shell fragments. FP, fecal pellet; VRF, volcanic rock fragment; SL, shale lithic; OM, organic matter. 3. Silt- to sand-size particles include all framework grains consisting of a single mineralogy and MCPs (also acting as framework grains) coarser than $20 \mu \mathrm{m}$.

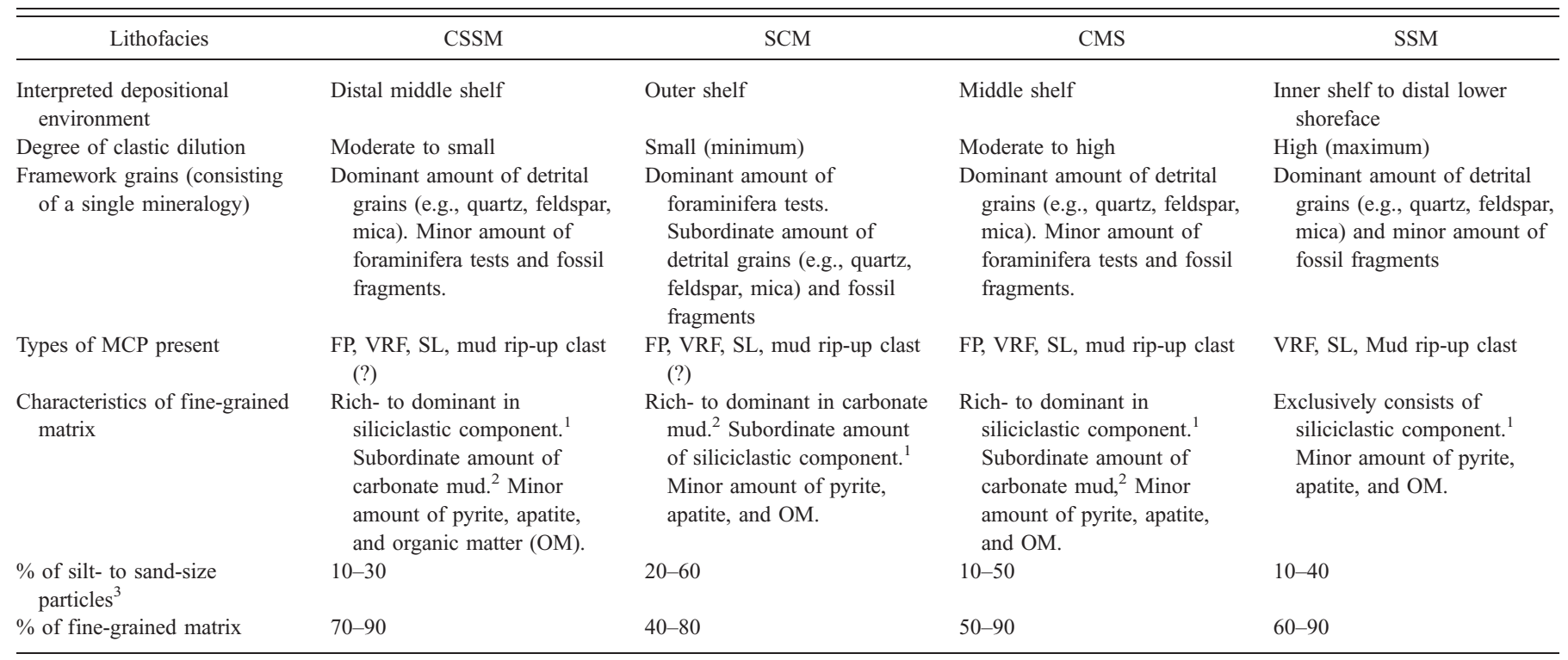

produced by planktonic grazers such as copepods that fed selectively upon coccolithophores (Hattin 1975; Honjo 1976).

Planktonic fecal pellets transport significant amounts of biogenic and lithogenic particles from the euphotic layer to the sediment-water interface (Honjo 1976, 1982; Minoura and Osaka 1992). Sinking rates of fecal pellets range from 50 to 225 meters per day (mean of $160 \mathrm{~m}$ per day), which is three orders of magnitude faster than that of an individual coccolith (Honjo 1976). Almost the entire succession of the Tununk Shale was deposited above the average storm-wave base for silt, which is less than $100 \mathrm{~m}$ deep in the WIS (Plint 2014; Li and Schieber 2018). Therefore, during deposition of the Tununk Shale, most fecal pellets produced by planktonic grazers would sink to the ocean bottom within a day without being severely dissolved or biodegraded.

In each general lithofacies type, variation in the abundance of fecal pellets is interpreted to be controlled dominantly by changes in sedimentation rate. Sand-size biogenic particles such as planktonic foraminifera and fecal pellets are transport-equivalent to quartz silt and can be transported as bedload (Nowell et al. 1981; Oehmig 1993). Concentration of fecal pellets in wavy laminae and wave-ripple cross lamination indicates transport and deposition of these particles under the influence of storm-induced bottom currents (Fig. 6). Relatively high sedimentation rates should also result in higher burial efficiency and better preservation of fecal pellets. On the other hand, when sedimentation rates are low and bottom waters are oxygenated (as suggested by common bioturbated texture), fecal pellets should be more prone to biodegradation and disintegration by mud-filtering benthos (Honjo 1976; Sethi and Leithold 1994), thus having less preservation potential (Figs. 6, 7).

Among all the lithofacies types that contain fecal pellets in the Tununk Shale, the SCM (silt-bearing, calcareous mudstone) facies has the highest relative number of fecal pellets compared to the CSSM (carbonate-bearing, silty and sandy mudstone) and CMS (carbonate-bearing, silty mudstone to muddy siltstone facies) (Table 4). There are probably several reasons for this. First, the silt-bearing, calcareous mudstone facies was deposited at the greatest water depth (still above the average storm-wave base for silt) and shows minimal clastic dilution (Fig. 3, Table 1). Second, benthic oxygen levels during deposition of the silt-bearing, calcareous mudstone facies were relatively low (but bioturbation is still present) compared to the other two facies, a factor that also favors the preservation of fecal pellets. Third, fecal pellets are likely resuspended by storm-induced bottom currents during deposition of the carbonate-bearing, silty and sandy mudstone and carbonate-bearing, silty mudstone to muddy siltstone facies, which accumulated in more energetic conditions at shallower water depth. Collision between fecal pellets and hard grains (e.g., quartz, feldspar, shell fragments, etc.) can result in breakage of fecal pellets and dispersal of coccoliths. This assumption is supported by the observation that despite the relatively small content of fecal pellets, a significant proportion of coccoliths occurs in the fine-grained matrix of the carbonate-bearing, silty and sandy mudstone and carbonate-bearing, silty mudstone to muddy siltstone (Table 1). Considering the rather slow sinking rate of individual coccoliths (Honjo 1976, 1982), coccoliths present in the carbonate-bearing, silty and sandy mudstone and carbonate-bearing, silty mudstone to muddy siltstone probably arrived at the seafloor in the form of fecal pellets originally.

\section{Volcanic Rock Fragments}

Volcanic rock fragments are a type of MCP commonly present throughout the Tununk Shale. The abundance of volcanic rock fragments appears to be inversely correlated to that of fecal pellets (Table 4). Most volcanic rock fragments identified in the Tununk Shale have equant to slightly elongated shapes with varying degrees of roundness (Table 2). The size of volcanic rock fragments ranges from fine silt to fine sand size in this study (Fig. 5, Table 3).

In the Tununk Shale, two types of volcanic rock fragments can be identified. Type 1 volcanic rock fragments share many characteristics with the bentonite beds in terms of mineral composition and texture. Both type 
TABLE 2.- Summary of petrographic characteristics of all four types of MCPs identified in the Tununk Shale.

\begin{tabular}{|c|c|c|c|c|}
\hline & Fecal Pellet (FP) & Volcanic Rock Fragment (VRF) & Shale Lithic (SL) & Mud Rip-Up Clast \\
\hline Shape (normal to bedding) & Oval-shaped and elongated & Equant to slightly elongated & Equant to slightly elongated & Elongated, highly "flattened" \\
\hline Shape (parallel to bedding) & $\begin{array}{l}\text { Similar with bedding-normal } \\
\text { view, irregular if indented } \\
\text { by harder grains }\end{array}$ & $\begin{array}{l}\text { Similar with bedding-normal view, } \\
\text { irregular if indented by harder grains }\end{array}$ & $\begin{array}{l}\text { Similar with bedding-normal } \\
\text { view, irregular if indented } \\
\text { by harder grains }\end{array}$ & Highly irregular \\
\hline $\begin{array}{l}\text { Element composition } \\
\text { (based on EDS) }\end{array}$ & $\begin{array}{l}\text { Dominant } \mathrm{Ca} \text { peak, } \\
\text { subordinate } \mathrm{Si} \text { and } \mathrm{Al} \text { peaks }\end{array}$ & $\begin{array}{l}\text { Type } 1 \text { : Dominant } \mathrm{Si} \text { and } \mathrm{Al} \text { peaks, small } \\
\mathrm{Mg}, \mathrm{Na} \text { peaks and varying degree of } \\
\mathrm{Ca}, \mathrm{Fe} \text {, and } \mathrm{K} \text { peaks } \\
\text { Type } 2 \text { : Dominant } \mathrm{Si} \text { and } \mathrm{Al} \text { peaks and } \\
\text { varying degree of } \mathrm{K}, \mathrm{Na}, \mathrm{Ca}, \mathrm{Mg}, \mathrm{Fe}\end{array}$ & $\begin{array}{l}\text { Dominant } \mathrm{Si} \text { and } \mathrm{Al} \text { peaks and } \\
\text { varying degree of } \mathrm{Ca}, \mathrm{K} \text {, } \\
\mathrm{Na}, \mathrm{Fe}\end{array}$ & $\begin{array}{l}\text { Dominant } \mathrm{Si} \text { and } \mathrm{Al} \text { peaks and } \\
\text { varying degree of } \mathrm{Fe}, \mathrm{K} \text {, } \\
\mathrm{Mg}, \mathrm{Na}\end{array}$ \\
\hline Mineral composition & $\begin{array}{l}\text { Almost exclusively coccolith } \\
\text { debris, some contain small } \\
\text { amount of amorphous } \\
\text { organic matter and clay- } \\
\text { mineral-like particles. }\end{array}$ & $\begin{array}{l}\text { Type 1: Dominantly smectite } \\
\text { (montmorillonite based on XRD } \\
\text { analysis); some contain micrometer-size } \\
\text { biotite fragments, K-spar, plagioclase, } \\
\text { quartz, apatite, and ilmenite. } \\
\text { Type 2: May contain intergrowth of } \\
\text { feldspar (both plagioclase and K-spar), } \\
\text { quartz, and biotite. }\end{array}$ & $\begin{array}{l}\text { Clay (dominantly smectite, } \\
\text { some illite, and chlorite)- } \\
\text { bearing to -rich, common } \\
\text { silt-size siliciclastic grains } \\
\text { (e.g., quartz, feldspar, and } \\
\text { biotite), small amount of } \\
\text { pyrite and organic matter. }\end{array}$ & $\begin{array}{l}\text { Clay-rich, common fine silt } \\
\text { sized grains (mostly quartz), } \\
\text { small amount of pyrite and } \\
\text { organic matter. }\end{array}$ \\
\hline $\begin{array}{l}\text { Characteristics in thin } \\
\text { sections (PPL) }\end{array}$ & $\begin{array}{l}\text { Greenish, brownish, to dark } \\
\text { brown color. FPs with } \\
\text { higher OM and/or clay } \\
\text { content usually show darker } \\
\text { colors. FPs commonly stand } \\
\text { out from their surrounding } \\
\text { more clay-rich, OM-bearing } \\
\text { matrix. }\end{array}$ & $\begin{array}{l}\text { Type 1: Greenish brown to dark brown } \\
\text { color, different from the color of } \\
\text { surrounding fine-grained matrix. } \\
\text { Particularly distinct if present in silt- } \\
\text { and sand-dominated laminae. } \\
\text { Type 2: Light-colored, challenging to } \\
\text { distinguish from quartz or feldspar } \\
\text { without sufficient resolution. }\end{array}$ & $\begin{array}{l}\text { Clay-dominated SLs } \\
\text { commonly have dark } \\
\text { brownish color, different } \\
\text { from the color of } \\
\text { surrounding fine-grained } \\
\text { matrix. Particularly distinct } \\
\text { if present in silt- and sand- } \\
\text { dominated laminae. SLs rich } \\
\text { in quartz silt can be light } \\
\text { colored. }\end{array}$ & $\begin{array}{l}\text { Commonly show dark brown } \\
\text { color. Particularly distinct if } \\
\text { present in silt- and sand- } \\
\text { dominated laminae }\end{array}$ \\
\hline $\begin{array}{l}\text { Characteristics in thin } \\
\text { sections }(\mathrm{CPL})\end{array}$ & $\begin{array}{l}\text { Carbonate micrite texture, } \\
\text { usually show greenish to } \\
\text { yellowish interference color. }\end{array}$ & $\begin{array}{l}\text { Type 1: Commonly low to slightly } \\
\text { yellowish interference color. VRFs with } \\
\text { a fair amount of Fe content look } \\
\text { greenish. } \\
\text { Type 2: Low interference color, similar } \\
\text { with quartz or feldspar }\end{array}$ & $\begin{array}{l}\text { Clay-dominated SLs show } \\
\text { relatively high interference } \\
\text { color due to preferential } \\
\text { orientation. SLs dominated } \\
\text { by quartz silt show low } \\
\text { interference color. }\end{array}$ & $\begin{array}{l}\text { Commonly low to slightly } \\
\text { yellowish interference color. }\end{array}$ \\
\hline $\begin{array}{l}\text { Characteristics under the } \\
\text { SEM }\end{array}$ & $\begin{array}{l}\text { Secondary electron images are } \\
\text { usually better at revealing } \\
\text { the outlines of fecal pellets } \\
\text { than backscattered images, } \\
\text { especially when the } \\
\text { surrounding fine-grained } \\
\text { matrix is also very } \\
\text { calcareous (rich in coccolith } \\
\text { debris). }\end{array}$ & $\begin{array}{l}\text { Particle outlines of both types of VRFs } \\
\text { can be effectively revealed in both } \\
\text { backscatter and secondary electron } \\
\text { images based on contrast in mineral } \\
\text { composition and texture with } \\
\text { surrounding matrix. Secondary electron } \\
\text { images are usually better at revealing } \\
\text { the intergrowth of multiple minerals in } \\
\text { type } 2 \text { VRFs. }\end{array}$ & $\begin{array}{l}\text { Particle outlines can be } \\
\text { effectively revealed in both } \\
\text { backscatter and secondary } \\
\text { electron images based on } \\
\text { contrast in mineral } \\
\text { composition and texture } \\
\text { with surrounding matrix. }\end{array}$ & $\begin{array}{l}\text { Challenging to distinguish } \\
\text { from enclosing fine-grained } \\
\text { matrix. When present in } \\
\text { silty and sandy laminae, the } \\
\text { outlines of rip-up clasts are } \\
\text { more readily identified. }\end{array}$ \\
\hline
\end{tabular}

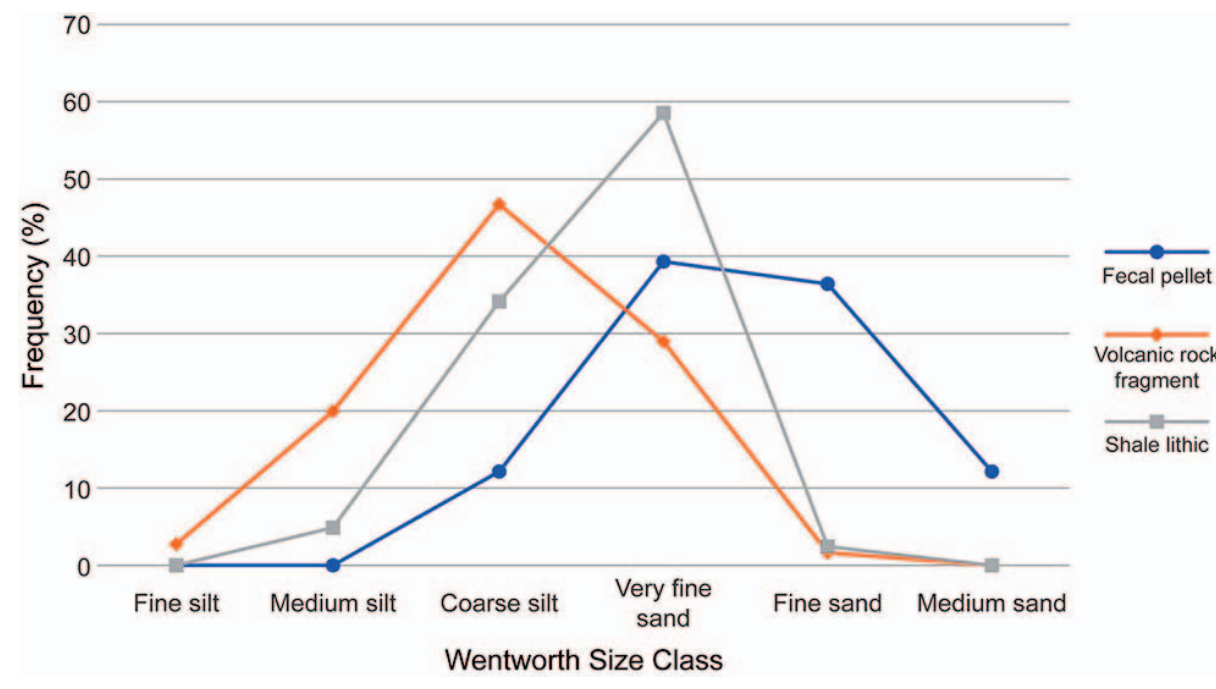

FIG. 5.-Distribution of grain size (length of the long axis) for all fecal pellets, volcanic rock fragments, and shale lithics identified in the Tununk Shale. Because only a small number of mud rip-up clasts $(\mathrm{N}=6)$ were observed in this study, their grain-size distribution is not shown here. 
TABLE 3.- Range of grain size and length-width ratio for each type of MCP documented in this study. All measurements were conducted using SEM photomicrographs of samples cut normal to bedding.

\begin{tabular}{|c|c|c|c|c|c|c|c|}
\hline Type of Composite Particles & $\begin{array}{c}\text { No. of Particles } \\
\text { Counted }\end{array}$ & \multicolumn{3}{|c|}{ Grain Size $(\mu \mathrm{m})$} & \multicolumn{3}{|c|}{ Length/Width Ratio } \\
\hline Fecal Pellet & 173 & 40.3 & 448.0 & 145.6 & 1.4 & 11.2 & 4.2 \\
\hline Volcanic Rock Fragment & 366 & 9.7 & 185.2 & 53.9 & 1.0 & 4.0 & 1.6 \\
\hline Shale Lithic & 41 & 26.3 & 163.4 & 76.3 & 1.0 & 2.9 & 1.7 \\
\hline Mud Rip-Up Clasts & 6 & 120.3 & 184.6 & 145.2 & 2.8 & 3.6 & 3.2 \\
\hline
\end{tabular}

1 volcanic rock fragments and bentonites are dominated by smectite. Some volcanic rock fragments contain micrometer-size (several to a few tens of micrometers) mineral grains such as biotite, potassium feldspar, plagioclase (commonly Ca-rich), quartz, apatite, and ilmenite, which are also common minerals in bentonites (Table 2). In thin sections, type 1 volcanic rock fragments show greenish brown to dark brown color under PPL and overall low to greenish or yellowish interference color under CPL (Table 2, Fig. 9). The presence and outlines of volcanic rock fragments are most clearly observed with SEM imaging (Fig. 10) where they show distinct contrast in mineral composition and texture with their surrounding finegrained matrix (Tables 1,2). When volcanic rock fragments are present in the fine-grained matrix, varying degrees of differential compaction can be observed around them (Fig. 10C). Volcanic rock fragments occurring in silty and sandy laminae or beds show resistance to compaction, but they also show indentation by surrounding harder grains such as quartz and feldspar (Fig. 10D-F).

Type 2 volcanic rock fragments may contain feldspar (both plagioclase and potassium feldspar), quartz, and biotite and commonly show intergrowth texture (Table 2). In thin sections, they are light-colored under PPL and show low interference color under CPL, similar to quartz and feldspar (Fig. 11). Due to small crystal size and limited resolution, the intergrown texture of type 2 volcanic rock fragments is not easily to be recognized in thin sections (Fig. 11). SEM analysis is much better at revealing the intergrown texture, as well as mineral composition and texture of type 2 volcanic rock fragments (Fig. 12). Under the SEM, type 2 volcanic rock fragments can be more readily identified based on distinct contrast in mineral composition and texture with their surrounding finegrained matrix (Fig. 12).

\section{Origin of Volcanic Rock Fragments}

Based on the gross similarity in clay mineralogy with bentonites, Nadeau and Reynolds (1981b) argued that approximately one third to half of the Cretaceous marine shales are of volcanic origin. The significant amount of volcanic input into the Tununk Shale is supported by the common occurrence of volcanic rock fragments observed in this study.
Type 1 volcanic rock fragments show essentially the same mineral composition and texture as bentonites in the Tununk Shale, suggesting a genetic link. Both bentonites and type 1 volcanic rock fragments are interpreted to be early diagenetic alteration products of volcanic ash (Fisher and Schmincke 1984). The influx of most original volcanic ash to the marine environment was likely wind transported and episodic (Nadeau and Reynolds 1981b). Deposition of a series of bentonite beds that are regionally continuous probably occurred during pulses of volcanic input. However, absence of ash beds does not imply absence of volcanic input. In addition to passive settling from above through the water column, volcanic ash is also subject to reworking by bioturbation and bottom currents (some bentonite beds in the Tununk Shale show bioturbated texture and ripplescale cross lamination). When the amount of volcanic input is relatively small, and/or when bottom conditions are energetic enough to completely rework and disperse all the incoming ash materials, no deposit indicating pulses of volcanic input (i.e., bentonite) will be left in the rock record. Instead, all the resuspended volcanic materials are likely to be redistributed by storm-induced bottom currents across and along the shelf. Bedload transport and deposition of type 1 volcanic rock fragments is supported by their common occurrence in the silty and sandy laminae or beds (Fig. 10D, F).

The presence of zoned plagioclase and intergrowth texture in the type 2 volcanic rock fragments indicates a volcanic origin. Based on mineral composition and texture, this type of volcanic rock fragments are interpreted as felsic rock fragments. In addition to transport by wind, the other possible source of volcanic rock fragments in the Tununk Shale is derived from rivers that drained the volcanic hinterland. Felsic rock fragments are durable enough to survive long-distance river transport (Cameron and Blatt 1971). The intergrown texture commonly observed in the type 2 volcanic rock fragments has not been observed in the small phenocrysts in altered volcanic ash (i.e., bentonite) beds, indicating different sources and transport mechanisms between these two types of volcanic rock fragments. Nevertheless, the presence of silt- to sand-size type 2 volcanic rock fragments in the silty and sandy laminae indicate that they are also subject to transport and deposition as bedload.

TABLE 4.- Semiquantitative estimation of the proportion of different types of MCPs in different lithofacies packages in the Tununk Shale. The abundance of each type of MCP is normalized to the content of silt-to sand-size particles (see Table 1) in each lithofacies. See Table 1 for the composition of framework grains consisting of a single mineralogy in different lithofacies packages. CSSM: carbonate-bearing, silty and sandy mudstone, SCM: silt-bearing, calcareous mudstone, CMS: carbonate-bearing, silty mudstone to muddy siltstone, and SSM: noncalcareous, silty and sandy mudstone.

\begin{tabular}{|c|c|c|c|c|}
\hline Lithofacies & Fecal pellets $(\%)$ & Volcanic rock fragments $(\%)$ & Shale lithics $(\%)$ & Other framework grains of a single mineralogy $(\%)$ \\
\hline CSSM & $0-20$ & 10 & $5-20$ & $50-80$ \\
\hline $\mathrm{SCM}$ & $70-90$ & $0-1$ & Trace & $10-30$ \\
\hline CMS & $0-1$ & $2-10$ & $2-10$ & $80-90$ \\
\hline SSM & 0 & $10-20$ & $5-30$ & $50-80$ \\
\hline
\end{tabular}



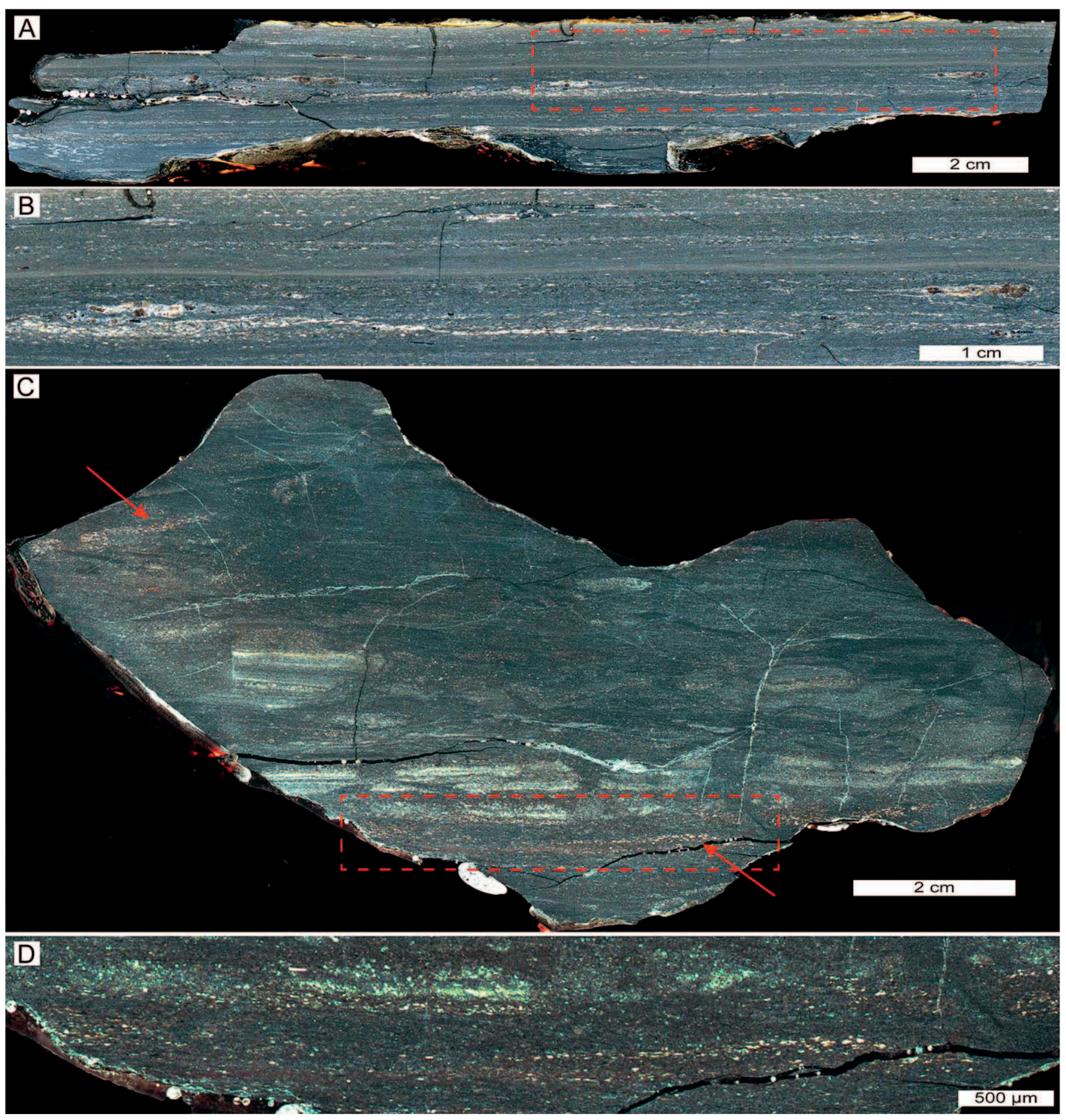

FIG. 6.-Characteristics of fecal pellets in scanned images of polished slabs cut normal to bedding. Samples from Parts A and C are both from the silt-bearing, calcareous mudstone facies, but from different stratigraphic levels. A) Common parallel to wavy laminae made dominantly of calcareous particles such as planktonic foraminifera tests, fecal pellets (white specks), and common shell fragments. B) Closer view of dashed area in Part A showing lamination caused by differing concentrations of fecal pellets. C) Common disrupted laminae made dominantly of calcareous particles. Laminae made dominantly of fecal pellets (white specks) are indicated by red arrows. Fecal pellets that are randomly scattered in the moderately bioturbated, fine-grained areas (suggested by petrographic examinations) are less readily recognized in polished slabs. D) Closer view of dashed area in Part C. 


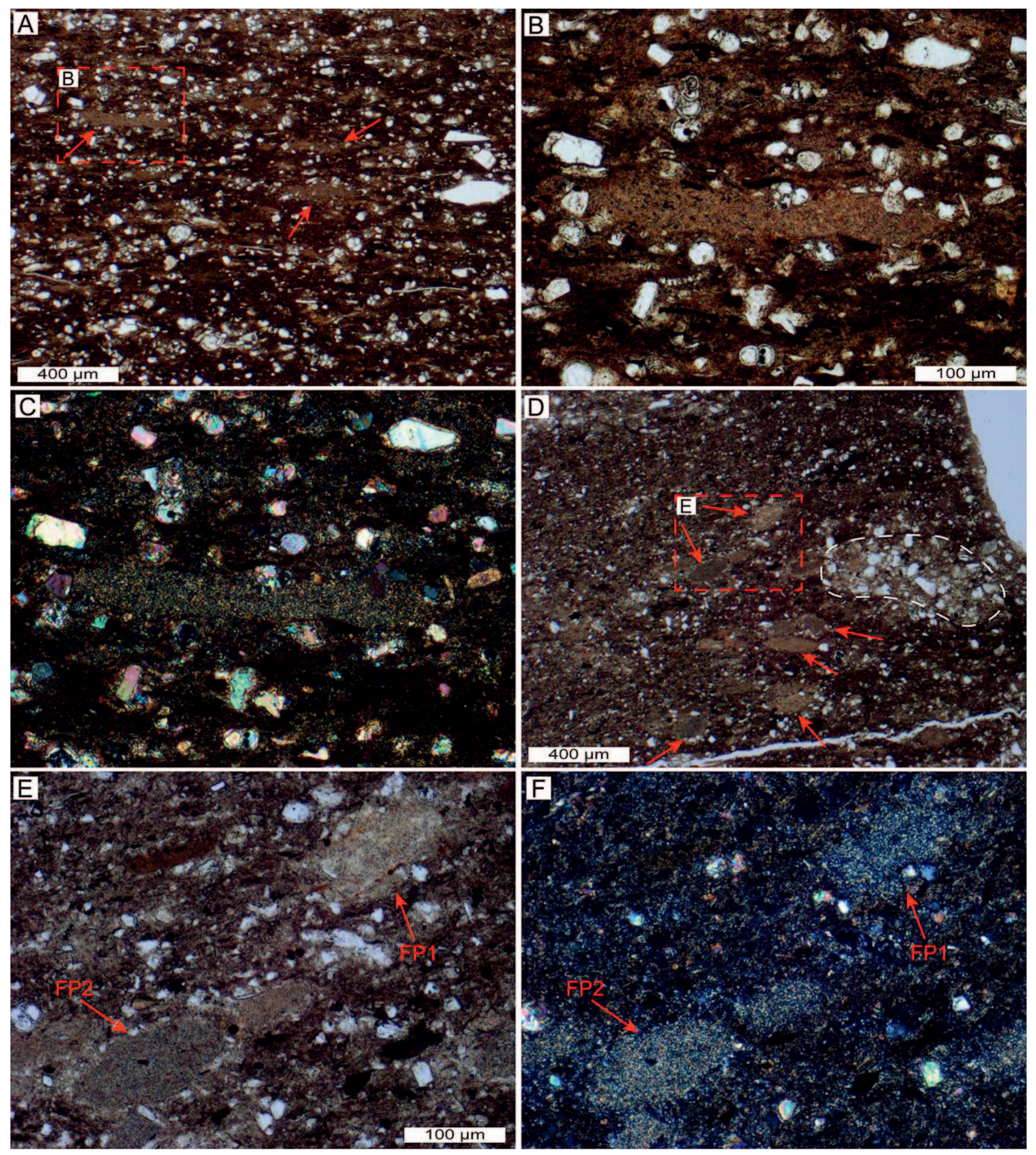

FIG. 7. - Characteristics of fecal pellets in thin sections. A) Photomicrograph showing common fecal pellets (red arrows) that show preferred orientation, from the siltbearing, calcareous mudstone facies (PPL). B, C) Closer view of the dashed area in Part A showing an elongated fecal pellet (PPL and CPL). The fecal pellet shows local indentation by harder grains (foraminiferal tests filled with calcite and shell fragments). D) Photomicrograph showing common fecal pellets (red arrows) scattered in an area, from the carbonate-bearing, silty mudstone to muddy siltstone facies (PPL). Note a small silt-filled burrow (white dashed outline) on the middle right of the image. Fecal pellets show at least two preferred orientations (horizontal and inclined) due to texture disruption by bioturbation. E, F) Closer view of the dashed area in Part D showing two inclined fecal pellets (PPL and CPL). Fecal pellet 1 (FP1) shows brownish color under PPL. Fecal pellet 2 (FP2) shows greenish color under PPL and brighter interference color under CPL. 

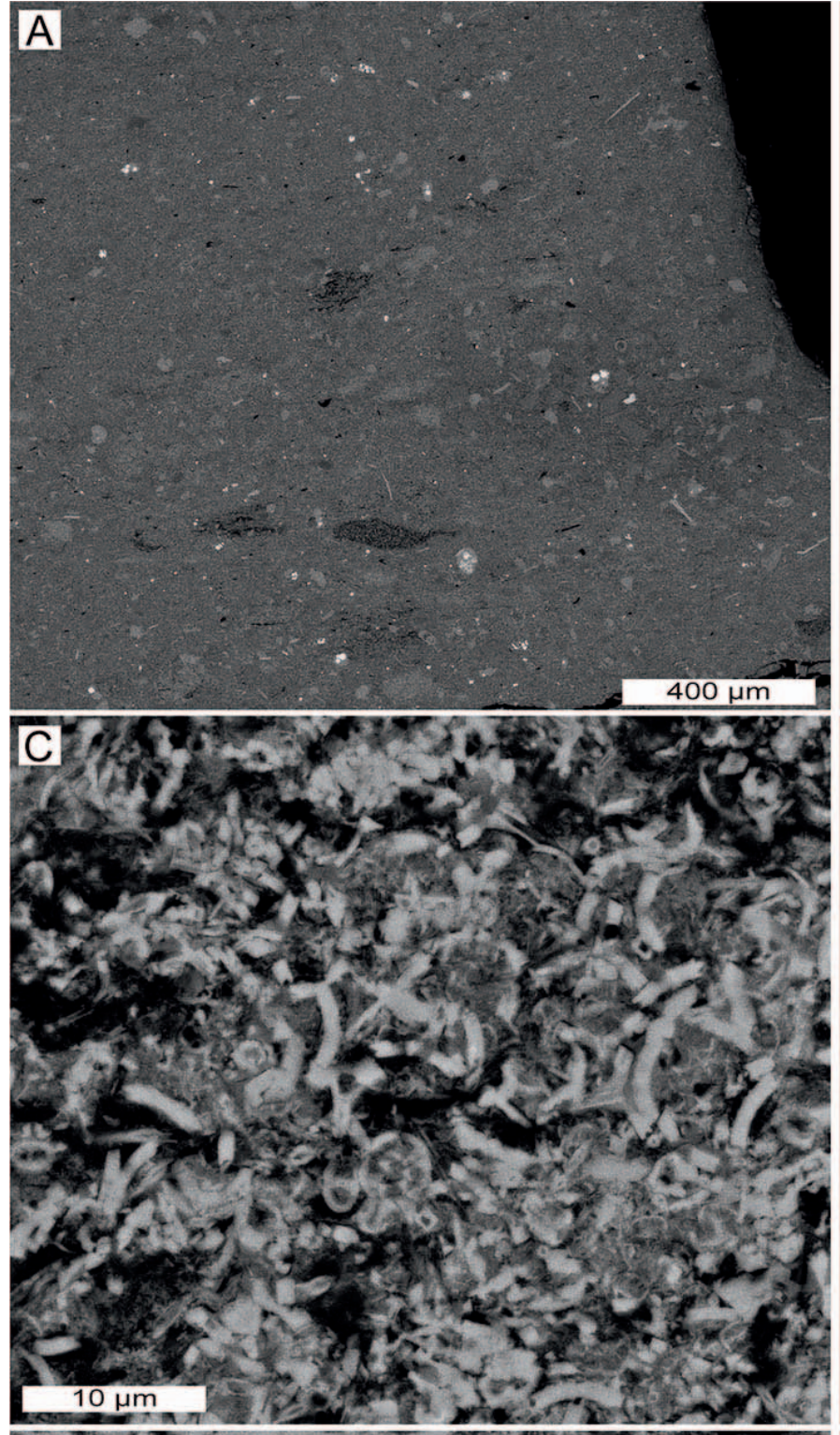

D (2)
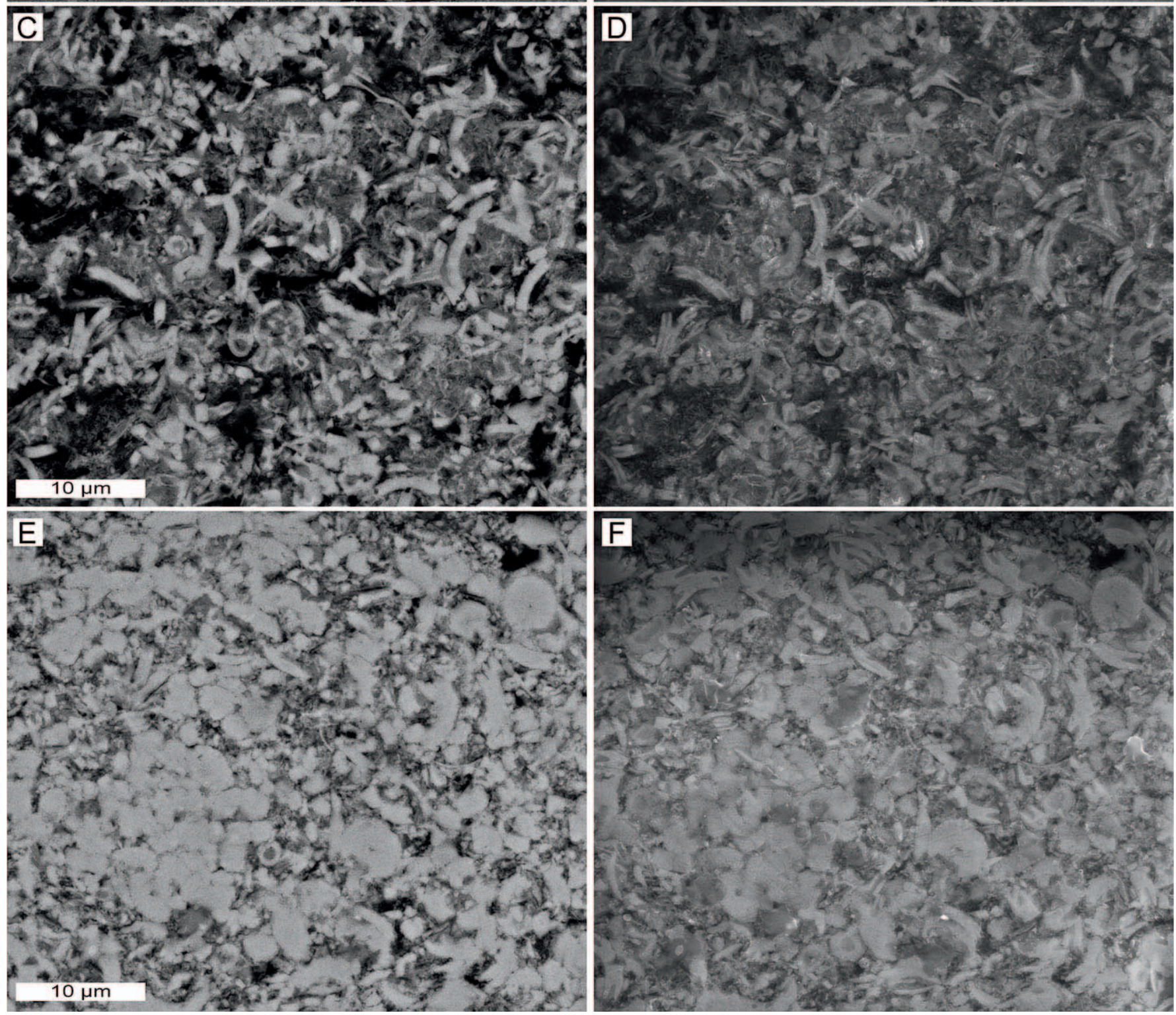


\section{Shale Lithics}

Shale lithics are another important type of MCP observed throughout the Tununk Shale (Table 4). Similar to volcanic rock fragments, most shale lithics are equant to slightly elongated with varying degrees of roundness (Table 2). Shale lithics range in size from medium silt to fine sand in this study (Fig. 5, Table 3).

Shale lithics in the Tununk Shale are clay- to silt-dominated composite particles (Table 2). A notable distinction as compared to fecal pellets and volcanic rock fragments is the common presence of fine silt $(<20 \mu \mathrm{m})$ grains (quartz, feldspar, etc.) (Fig. 10D). Small amounts of pyrite may also occur in some shale lithics. If clay dominates, most shale lithics show dark brown color under PPL, and have relatively high interference color under CPL due to preferred orientation of clays (Fig. 13). Shale lithics dominated by quartz silt are light colored under PPL, and show relatively low interference color under CPL (Fig. 13F). Under the SEM, shale lithics that have distinctly different mineral composition compared to their surrounding matrix are readily identified (Fig. 14). Distinguishing clay-dominated shale lithics from the enclosing fine-grained matrix can be challenging but is aided by textural differences such as preferred orientation of clays in shale lithics and differential compaction around them (Fig. 14). Most shale lithics do not appear to have suffered significant vertical shortening caused by burial compaction. When present in silty and sandy laminae, shale lithics are prone to show indentation by surrounding harder grains (Fig. 14).

\section{Origin of Shale Lithics}

Shale lithics are rock fragments derived from older strata of mudstone/ shale, and therefore show the same characteristics as fully compacted mudstones. Clay-dominated shale lithics are characterized by abundant fine silt grains and preferred orientation of clays. The latter can appear similar to compaction induced preferred compaction in the enclosing matrix, but lithic-internal preferred orientation not aligning with that in the matrix, as well as differential compaction around shale lithics, helps to make the distinction (note the preferred orientation of the Tununk matrix due to compaction shown in Fig. 13F).

Recent flume experiments indicate that shale lithics are durable enough to survive long-distance (hundreds to thousands of kilometers) river transport as well as further transport in shelf seas (Schieber 2016b). Shale lithics in the Tununk Shale could be derived from unroofing of some older fully compacted mudstone/shale successions exposed by the rising Sevier orogenic belt. An additional source for the shale lithics in the Tununk Shale could be the lacuna located in northeastern Utah (Fig. 1B). The lacuna represents a submarine unconformity, from where the deposited Cenomanian marine shale was entirely removed by constant reworking and erosion by wave-induced currents (Ryer and Lovekin 1986). Shale lithics derived from the lacuna could then have been transported southward by storminduced longshore currents, and finally deposited in south-central Utah. Similarly to the volcanic rock fragments, the presence of shale lithics in silty and sandy laminae indicate that shale lithics are also subject to bedload transport.

\section{Mud Rip-Up Clasts (Intraclasts)}

Another type of MCP present in the Tununk Shale are mud rip-up clasts. Compared to the other three types of MCP, mud rip-up clasts cannot always be recognized with confidence. Nevertheless, the MCPs presented in Figures 15 and 16 can be identified as mud rip-up clasts based on several criteria. Firstly, all the images in Figure 15 were taken from areas in very fine-grained sandstone beds showing wave-ripple or combined-flow-ripple cross lamination. Under the conditions when rippled sandstone beds were deposited, it is more likely for muds to be transported and deposited as MCPs rather than as discrete clay and silt particles. Secondly, these MCPs show a significant degree of vertical shortening and deformation caused by burial compaction on sections cut normal to bedding (Figs. 15, 16A-C) and highly irregular shapes on sections cut parallel to bedding (Fig. 16D, E), suggesting that the original clasts had high water contents (e.g., $\sim 70$ vol\%, Fig. 16C). Thirdly, all the MCPs show textures suggestive of bending and squeezing and act as "supporting" grains (Figs. 15, 16) instead of loose material that collapsed between hard sand grains (e.g., quartz and feldspar).

Mud rip-up clasts consist of clays and varying amounts of fine-silt-size minerals (mostly quartz) and a small amount of pyrite. Those documented in this study range from very fine sand to fine sand in size (Table 3 ). In thin sections, mud rip-up clasts show dark brown color under PPL and are prone to show overall low-order interference color under CPL (Fig. 15). Due to the close compositional similarity and minimal contrast in optical properties (Tables 1,2), it is rather challenging to recognize mud rip-up clasts when they are enclosed in a fine-grained matrix. When surrounded by translucent grains such as quartz and feldspar, mud rip-up clasts are more readily identified, even though they may be strongly deformed between adjacent harder grains (Figs. 15, 16). Compared to optical microscopy, SEM imaging is better suited to show the outlines of mud ripup clasts (Fig. 16).

\section{Origin of Mud Rip-Up Clasts}

In the Tununk Shale, mud rip-up clasts are interpreted to be the product of storm reworking of surficial or shallowly buried muds that had become sufficiently cohesive to resist disaggregation during erosion (Macquaker and Gawthorpe 1993; Schieber et al. 2010; Plint 2014). During deposition of the Tununk Shale, frequent storm reworking of the bottom is reflected in the common occurrence of erosional features and storm-generated sedimentary structures throughout the entire succession (Fig. 3). Recent flume experiments have demonstrated that muds can be deposited as floccules or mud rip-up clasts in the $15-30 \mathrm{~cm} / \mathrm{s}$ flow-velocity range (Schieber et al. 2007, 2010), which is in the same range as oscillatory currents capable of generating small wave ripples in very fine and fine sands ( $\sim 20$ to $40 \mathrm{~cm} / \mathrm{s}$ as suggested by Arnott and Southard 1990; Dumas et al. 2005) (Fig. 15).

\section{DISCUSSION}

\section{Recognition of Mud-Dominated Composite Particles with Petrographic Methods}

Three distinct types of MCPs that can be recognized in the Tununk Shale include fecal pellets, volcanic rock fragments, and shale lithics. When present in silt- and sand-dominated laminae, MCPs with comparable grain size visibly stand out from the surrounding "clean" particles composed of one mineral. When they are "floating" in fine-grained matrix, it is not always easy to recognize and distinguish specific types of MCPs in

FIG. 8.- Characteristics of fecal pellets under the SEM. A, B) Overview of the same area as Figure 7D under the SEM (backscatter and secondary electron images).

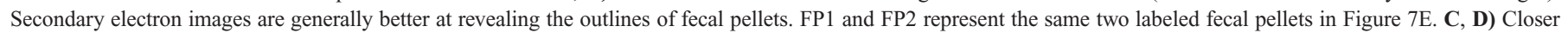

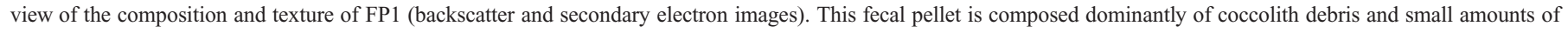

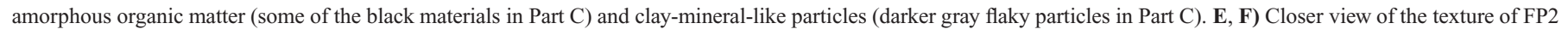
(backscatter and secondary electron images). This fecal pellet consists almost exclusively of coccolith debris. 


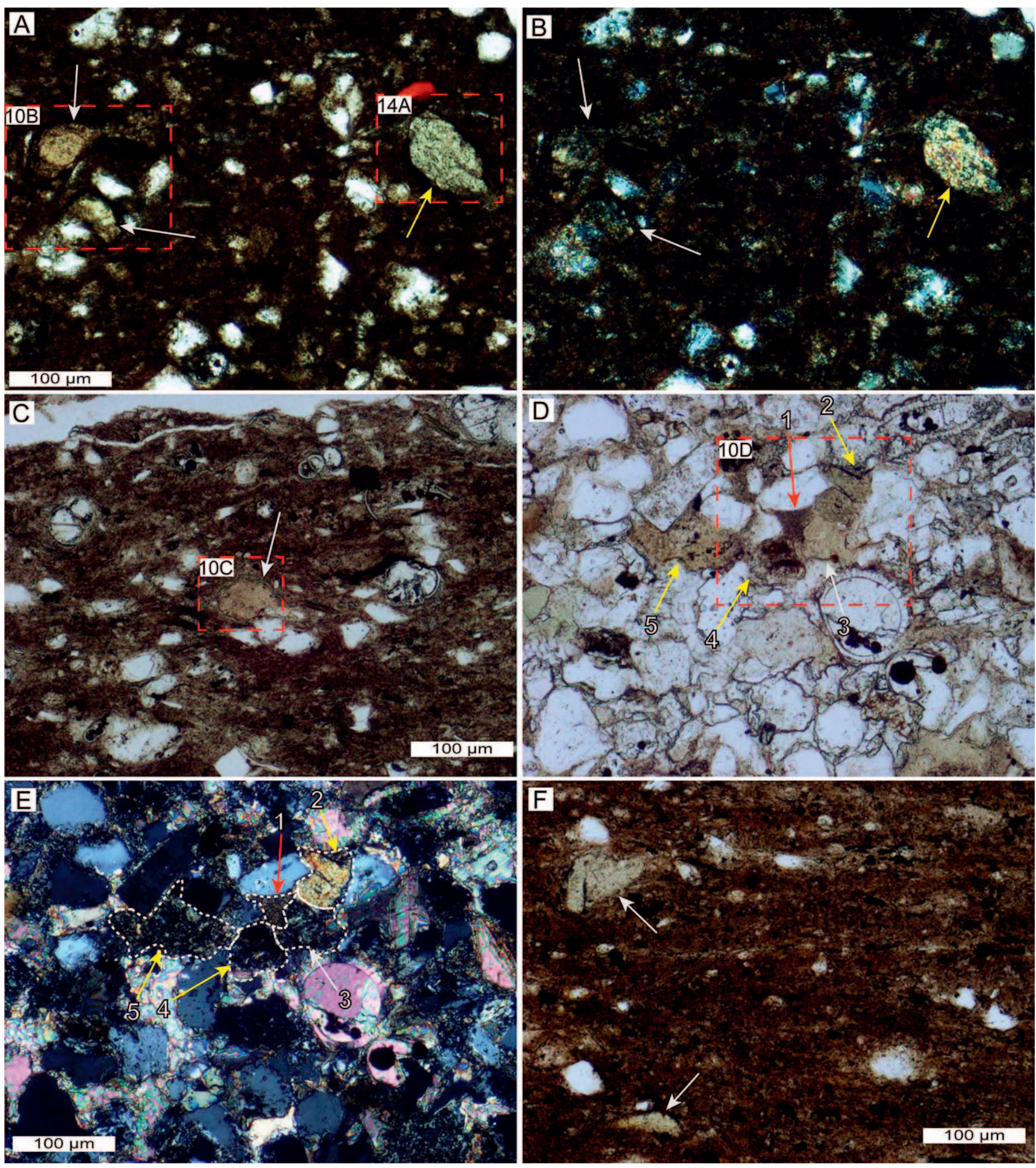

Fig. 9.-Characteristics of type 1 volcanic rock fragments in thin sections. Volcanic rock fragments, fecal pellets, and shale lithics are indicated by white, red, and yellow arrows, respectively. Identification of the various types of MCPs is confirmed based on SEM examinations. A, B) Overview of an area in the carbonate-bearing, silty and sandy mudstone facies showing the presence of two volcanic rock fragments and one shale lithic (PPL and CPL). C) One volcanic rock fragment present in an area of the carbonate-bearing, silty and sandy mudstone facies. D, E) Overview of an area in a silty lamina that consists of detrital grains (e.g., quartz and feldspar) and foraminifera tests filled with early diagenetic calcite (PPL and CPL). The view is from the carbonate-bearing, silty mudstone to muddy siltstone facies and shows at least five MCPs. The outlines for the five labeled MCPs are indicated in Part E. Note slight differences in color among all MCPs in Part D. F) Two volcanic rock fragments present in an area of the noncalcareous, silty and sandy mudstone (PPL). 


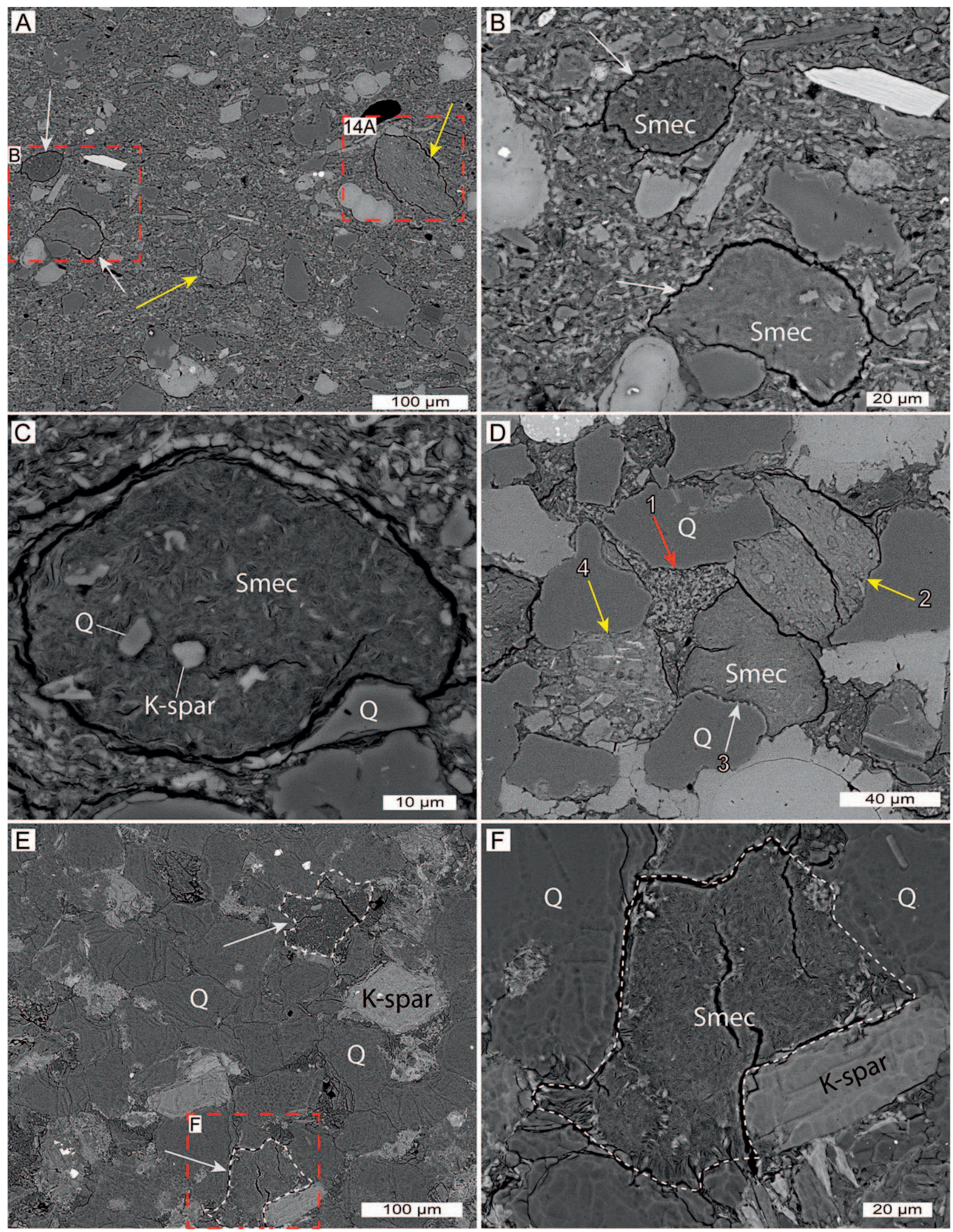



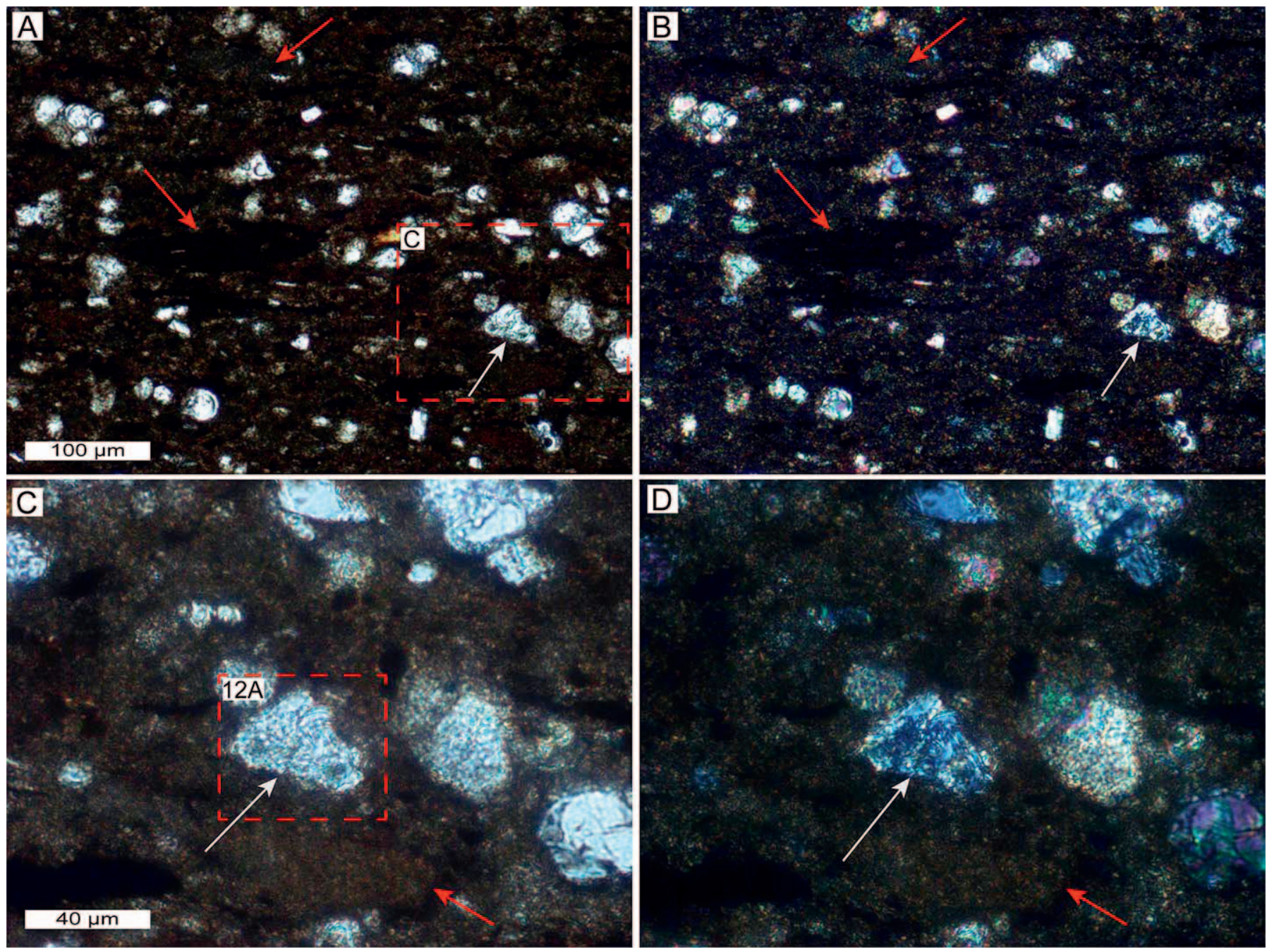

FIG. 11.-Characteristics of type 2 volcanic rock fragments in thin sections. Volcanic rock fragments and fecal pellets are indicated by white and red arrows, respectively. A, B) Overview of an area in the silt-bearing, calcareous mudstone facies showing the presence of one volcanic rock fragment and multiple fecal pellets (PPL and CPL). C, D) Closer view of the volcanic rock fragment in the dashed area in Part A (PPL and CPL). This volcanic rock fragment shows intergrowth of quartz and small biotite flakes. Biotite can be identified based on greenish color and relatively high interference color under PPL and CPL, respectively. Due to small crystal size, it is not always easy to distinguish type 2 volcanic rock fragments from quartz/feldspar in thin sections.

thin section, mainly due to limited resolution associated with small grain size and limited lithologic contrast in mudstones.

The grain size of MCPs identified in this study ranges from fine silt $(10 \mu \mathrm{m})$ to medium sand size $(448 \mu \mathrm{m})$ (Fig. 5, Table 3). Only MCPs larger than $40 \mu \mathrm{m}$ are easily identified in thin sections because particles smaller than the thin-section thickness $(20-30 \mu \mathrm{m})$ are masked by adjacent particles. When examined under the SEM, MCPs as small as 20 $\mu \mathrm{m}$ can be recognized based on their contrast with the enclosing matrix. Recognition of small (fine-silt-size) MCPs is greatly facilitated by ionmilled surfaces.

FIG. 10.-Characteristics of type 1 volcanic rock fragments under the SEM. Volcanic rock fragments, fecal pellets, and shale lithics are indicated by white arrow, red arrow, and yellow arrows, respectively. A) Overview of the same area as Figure 9A under the SEM (backscatter electron image). Note how the small MCP (a shale lithic) in the central area of this view can barely be distinguished in thin section (Fig. 9A). B) Closer view of the two smectite-dominated volcanic rock fragments marked in the red dashed area in Part A. Smec, smectite. The fine-grained matrix of the carbonate-bearing, silty and sandy mudstone facies consists of a dominant amount of siliciclastic clays and fine silt and common coccolith debris. C) Closer view of the volcanic rock fragment shown in the red dashed box in Figure 9C. This volcanic rock fragment contains micrometersize quartz and potassium feldspar (K-spar) in a smectite-dominated matrix (note the crenulated morphology), and has essentially the same composition and texture as bentonite. The lower right corner of the volcanic rock fragment is slightly indented by a harder quartz grain $(\mathrm{Q})$, and there is differential compaction around the volcanic rock fragment. The volcanic rock fragment contrasts in composition with the surrounding calcareous fine-grained matrix (note the presence of coccolith debris) and is therefore easy to recognize. D) Closer view of the same four MCPs shown in the red dashed box in Figure 9D (with same labels). Particle 1 (fecal pellet) consists exclusively of coccolith debris and has been squeezed between surrounding grains. Particles 2 and 4 are shale lithics (note the preferred orientation in particle 2 and the common presence of quartz silt in both particles). The smectite-dominated particle 3 is recognized as a volcanic rock fragment that has been indented by a harder quartz grain (Q). E) Two smectitedominated volcanic rock fragments in sandy wave-ripple cross lamination in the noncalcareous, silty and sandy mudstone facies. Both volcanic rock fragments are strongly indented and squeezed by surrounding harder grains. F) Closer view of the volcanic rock fragment in the red dashed box in Part E. All are backscatter electron images. 

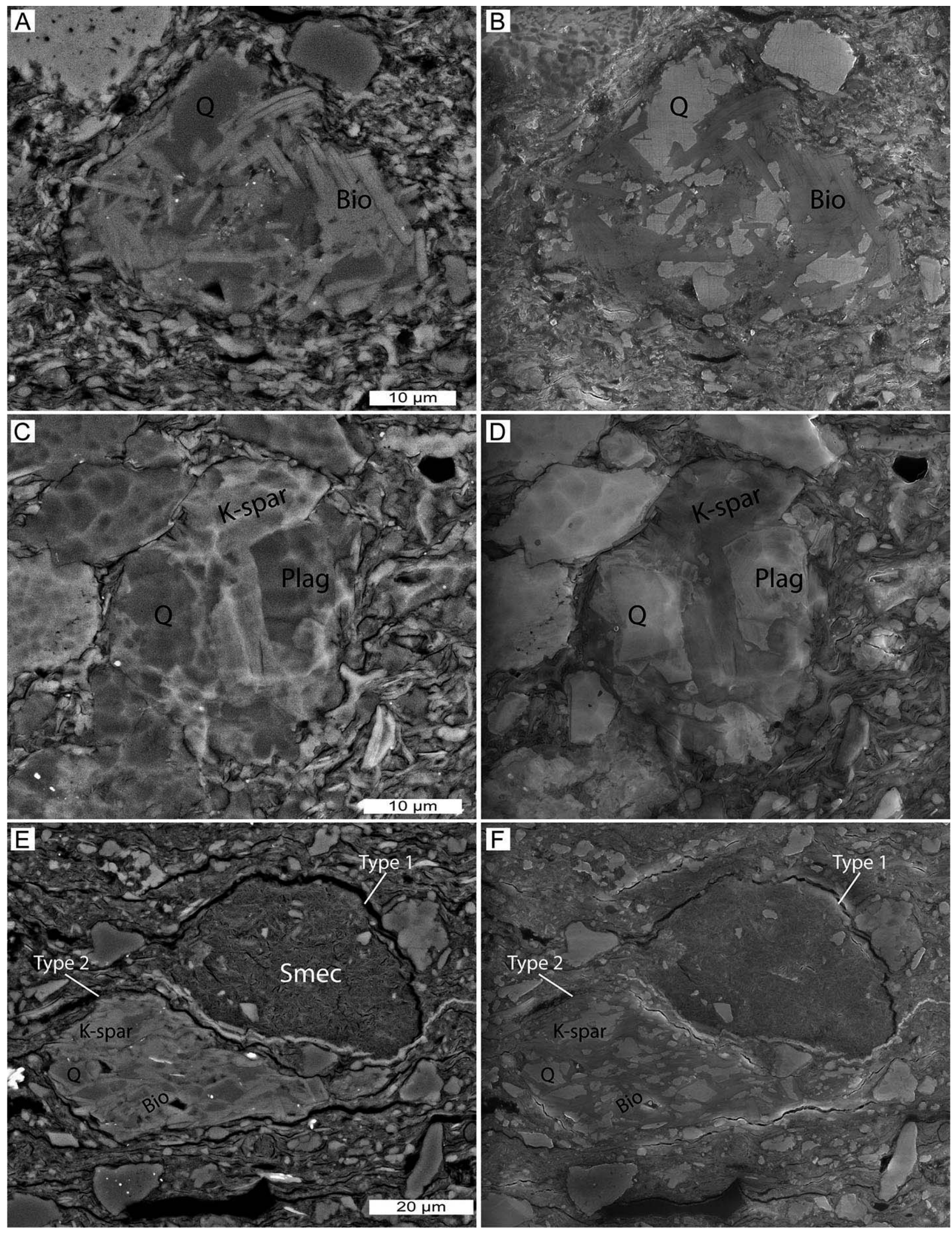
Nonetheless, not all MCPs larger than $40 \mu \mathrm{m}$ are readily discernible in thin sections. As shown in both Tables 1 and 2, each type of MCP, as well as their surrounding fine-grained matrix, shows a range of mineral composition and texture. This leads to overlapping optical characteristics between different types of MCPs and the matrix, a situation that can make it rather challenging to distinguish them from each other. Combined with the muted lithologic-contrast characteristics of mudstones, thin-section observation is therefore at a disadvantage for resolving MCPs when compared to SEM (based on comparison of identical areas examined through both optical microscopy and SEM). In addition, the specific type of MCP can be unequivocally determined only on the basis of mineral composition and texture as revealed through SEM analysis, especially when MCPs show similarity to other "dirty" particles, such as phosphate particles and weathered feldspars in thin sections (Fig. 13A, C). Therefore, optical microscopy has to be integrated with SEM analysis in order to get a firm understanding of the MCP population in mudstones.

\section{Significance of Water-Rich MCPS}

In the silt-bearing, calcareous mudstone facies, which was deposited at the greatest water depth in the most distal environment, the relative abundance of MCPs that can be distinctly identified (mostly fecal pellets and a minor amount of volcanic rock fragments and shale lithics) can be more than $50 \%$ (Tables 1, 4). Bedload transport in the silt-bearing, calcareous mudstone facies is reflected by the common presence of wavy laminae and wave-ripple cross lamination made dominantly of fecal pellets and foram tests. Compared to the silt-bearing, calcareous mudstone facies, bedload transport should play an even more significant role in the formation of the other three lithofacies packages (i.e., carbonate-bearing, silty and sandy mudstone, carbonate-bearing, silty mudstone to muddy siltstone, and noncalcareous, silty and sandy mudstone) deposited in shallower and more energetic environments. However, the relative abundance of distinct MCPs in these facies is only up to 10-20\% (Tables $1,4)$. In addition to fecal pellets, VRFs, and shale lithics, two types of water-rich MCPs, namely floccules and mud rip-up clasts, are probably present and constitute a significant portion of the fine-grained matrix.

The common occurrence of storm-generated erosional surfaces and sedimentary structures (Fig. 3), as well as the shallow bathymetry associated with the lacuna located in northeastern Utah (Fig. 1; Ryer and Lovekin 1986), all point to the likely formation of mud rip-up clasts via bottom-current-induced erosion of surficial muds (Schieber et al. 2010; Plint 2014; Li and Schieber 2018). Because the original muds were likely deposited via bedload transport of mud floccules, derived mud rip-up clasts and floccules would have very similar composition, unless the former was sourced from an environment that differed significantly from that of their final site of deposition. In the depositional setting envisioned for the Tununk Shale, sediments underwent multiple cycles of deposition and resuspension in the course of along- and across-shelf transport ( $\mathrm{Li}$ and Schieber 2018), conditions that would have been conducive to great reduction in compositional differences between floccules and mud rip-up clasts.

Except for components owing their origin to early diagenesis (e.g., pyrite, calcite cement, etc.), the composition of the fine-grained matrix in the Tununk Shale is essentially that of floccules (clay and fine silt; Table 1) that were the initial bed-forming particles. Micrometer-scale coccolith debris seen in the matrix of the lower calcareous interval of the Tununk Shale was likely integrated into floccules during transport due to small particle size (Schieber et al. 2013). Although bottom-current transport of floccules and mud rip-up clasts is increasingly recognized as a key element of marine mud transport on the basis of flume experiments and the study of modern environments (Schieber et al. 2007; Schieber and Southard 2009; Schieber 2011; Yawar and Schieber 2017; Shchepetkina et al. 2018), to identify floccules and mud rip-up clasts in ancient rocks, such as the Tununk Shale, is very challenging because both particle types are waterrich and severely flattened and deformed during burial and compaction, as well as disrupted by bioturbating organisms (Schieber et al. 2010; Schieber 2016b; Shchepetkina et al. 2018). The close compositional similarity between floccules, mud rip-up clasts, and the generic mud matrix of the Tununk further complicate this task, and we therefore consider it rather challenging to identify floccules and mud rip-up clasts in the Tununk Shale matrix with confidence by either optical microscopy or SEM. In places, however, favorable circumstances like sufficient compositional contrast (e.g., when present in silty and sandy laminae) provides hints regarding their former presence. As a final point one may also want to consider that evaluation of the whole range of transport processes that may move mud in epicontinental basins, bottom currents that would have reworked the seabed and transported silt, flocculated mud, and mud-rip-up clasts in bedload, are the only processes that are likely to have mattered in offshore regions of epicontinental seas (Schieber 2016a). These currents were likely driven by seasonal winds, and may have been aided by tidal currents, intermittent storm reworking of the muddy substrate, and lowering of sea level.

\section{The Link between Depositional Environment and Characteristics of MCPs}

Identification of the various types of MCPs and their texture in mudstones can yield important information regarding their depositional setting and provenance. The relationship between different textures of three distinct types of MCPs and different depositional environments of the Tununk Shale is summarized in Figure 17.

In the outer-shelf environment, sources of sediment supply are dominantly from primary productivity with a minor amount of terrestrial input ( $\mathrm{Li}$ and Schieber 2018). As a result, MCPs in the resulting siltbearing, calcareous mudstone are dominated by fecal pellets (Fig. 17, Table 4). Influenced by storm-induced bottom currents, fecal pellets tend to concentrate and form parallel to slightly wavy laminae (Figs. 6A, 17). Although locally some fecal pellets are slightly deformed and indented by foraminifera tests during compaction, the original shape and texture of fecal pellets in this setting is generally well preserved (Fig. 17).

In the middle-shelf environment, the relative amount of terrestrial input was larger. With shallower water depth, bioturbation intensity also generally increases in the carbonate-bearing, silty and sandy mudstone and carbonate-bearing, silty mudstone to muddy siltstone facies ( $\mathrm{Li}$ and Schieber 2018). Commonly, fecal pellets, volcanic rock fragments, and shale lithics in these facies are randomly scattered in the fine-grained

FIG. 12.-Characteristics of type 2 volcanic rock fragments under the SEM. A, B) Closer view of the volcanic rock fragment in the red dashed box in Figure $11 \mathrm{C}$. This volcanic rock fragment shows intergrowth of quartz (Q) and biotite (Bio). C, D) Closer view of a type 2 volcanic rock fragment in the carbonate-bearing, silty mudstone to muddy siltstone facies. This volcanic rock fragment consists of quartz, potassium feldspar (K-spar), and plagioclase (Plag). The plagioclase exhibits compositional zoning under the secondary electron mode (D), indicating a volcanic origin. Note that the edge of this volcanic rock fragment has been slightly altered into clays. E, F) An area showing both types of volcanic rock fragments in the noncalcareous, silty and sandy mudstone facies. The fine-grained matrix of the noncalcareous, silty and sandy mudstone facies consists exclusively of siliciclastic clays and fine silt (mostly quartz). The type 1 volcanic rock fragment consists dominantly of smectite (montmorillonite) and small crystals of potassium feldspar. The type 2 volcanic rock fragment shows intergrowth of quartz, potassium feldspar, and biotite. Note differential compaction around both volcanic rock fragments. Parts A, C, and E were acquired in backscatter electron mode. Parts B, D, and F were acquired in secondary electron mode. 

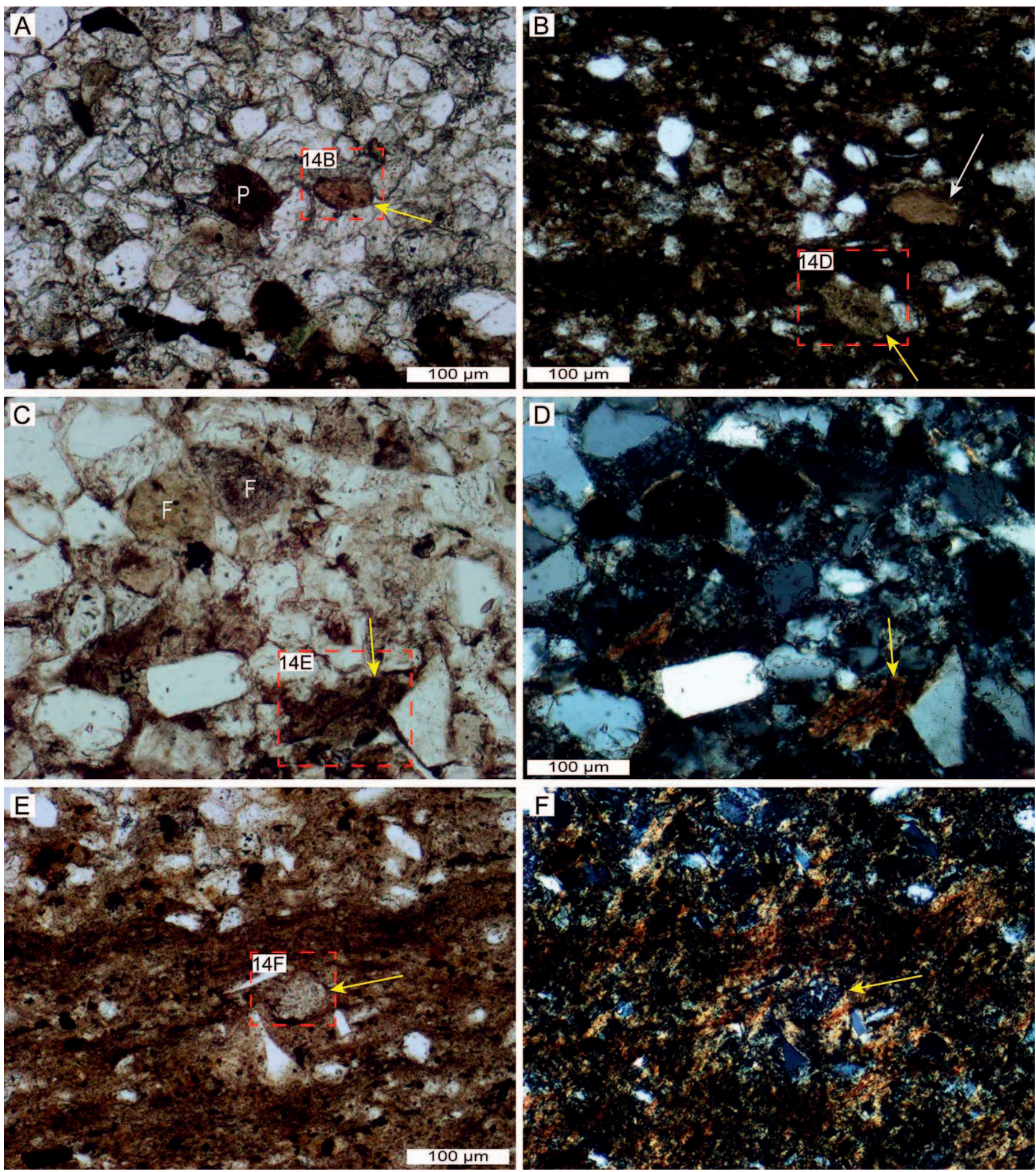

Fig. 13. - Characteristics of shale lithics in thin sections. Shale lithics and volcanic rock fragments are represented by yellow and white arrows, respectively. A) One shale lithic in a silty lamina made of detrital grains and foraminifera tests, from the carbonate-bearing, silty mudstone to muddy siltstone facies (PPL). P, phosphate. B) One shale lithic and one volcanic rock fragment (both verified with SEM) occur in the fine-grained matrix of the noncalcareous, silty and sandy mudstone facies (PPL). C, D) One shale lithic in a sandy lamina in the noncalcareous, silty and sandy mudstone facies (PPL and CPL). The relatively high interference color of the shale lithic is caused by preferred orientation of clays due to compaction. F, weathered feldspar. E, F) A shale lithic in the fine-grained matrix in the noncalcareous, silty and sandy mudstone facies (PPL and $\mathrm{CPL}$ ). Note that the fine-grained matrix shows relatively high interference color (due to preferred orientation resulting from compaction) relative to the shale lithic. 



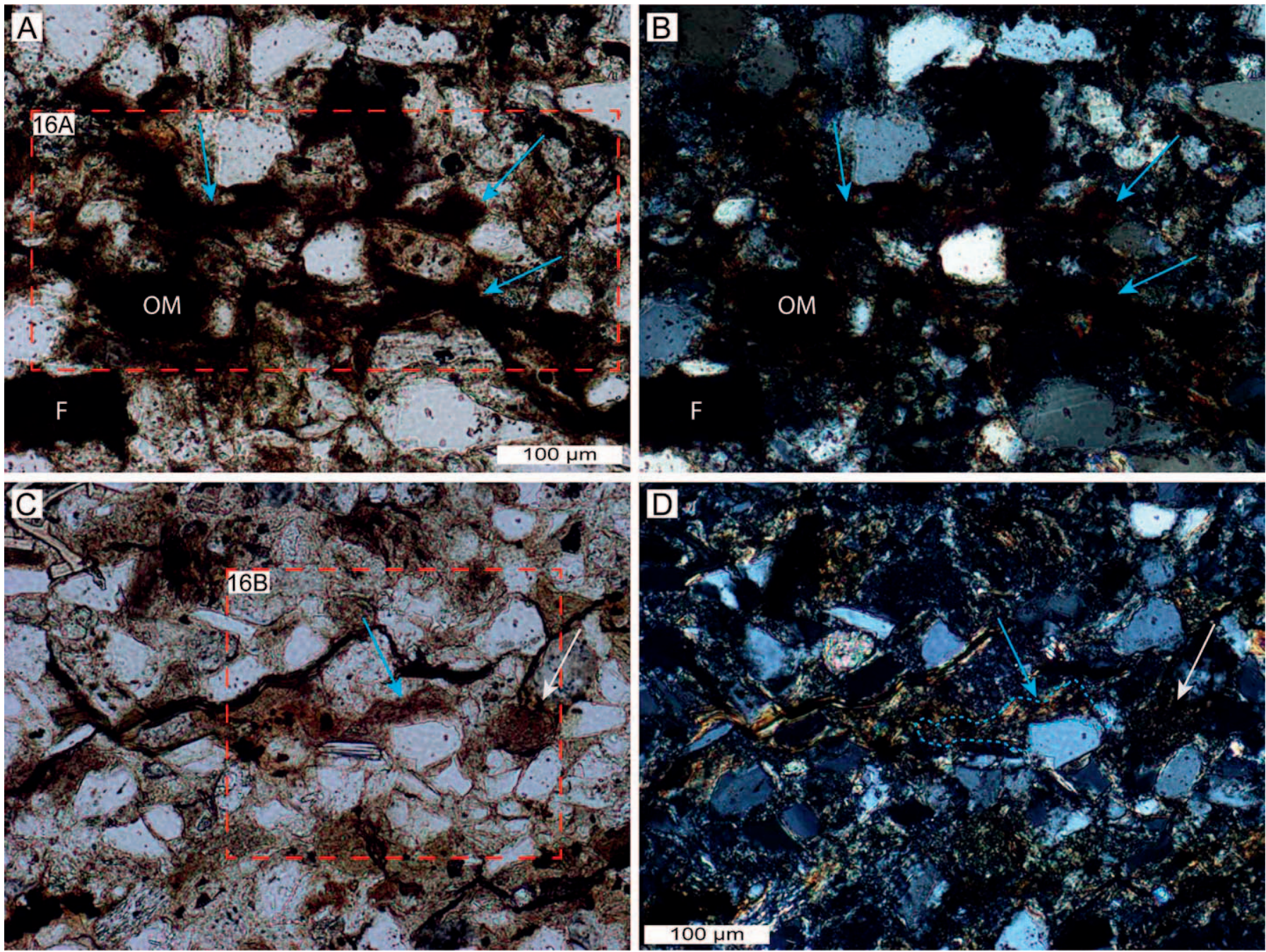

FIG. 15. - Characteristics of mud rip-up clasts in thin sections. Mud rip-up clasts and volcanic rock fragments are represented by blue and white arrows, respectively. A, B) Overview of an area showing muddy foresets in a sandy rippled bed, from the noncalcareous, silty and sandy mudstone facies (PPL and CPL). At least three mud rip-up clasts are present. OM, organic matter; F, weathered feldspar. C, D) One mud rip-up clast and one volcanic rock fragment (both verified with SEM) in a wave-rippled sandstone bed in the noncalcareous, silty and sandy mudstone facies (PPL and CPL). The interference color of the rip-up clast indicates some degree of preferred orientation of clays due to compaction. The blue dashed outline of this rip-up clast highlighted in Part D is based on SEM analysis.

matrix due to disruption by bioturbation (Figs. 6B, 17). Fecal pellets can also show preferential orientation and form laminae, indicating the influence of bottom currents. Silt- to sand-size volcanic rock fragments and shale lithics can be mixed with detrital grains (e.g., quartz, feldspar) and foraminifera tests of comparable grain size to form laminae. Overall, all three types of MCPs in these facies are prone to indentation by adjacent "hard" terrestrial-derived silt grains (quartz, feldspar, etc.).
In the inner-shelf environment, sediment supply is dominated by terrestrial input. No fecal pellets were identified in the noncalcareous, silty and sandy mudstone facies (Fig. 17). When surrounded by the fine-grained matrix, volcanic rock fragments and shale lithics commonly show indentation by harder silt and sand grains, and may show differential compaction of the surrounding matrix. When present in silty and sandy laminae, most volcanic rock fragments and shale lithics are indented or deformed by surrounding harder grains (Fig. 17). 

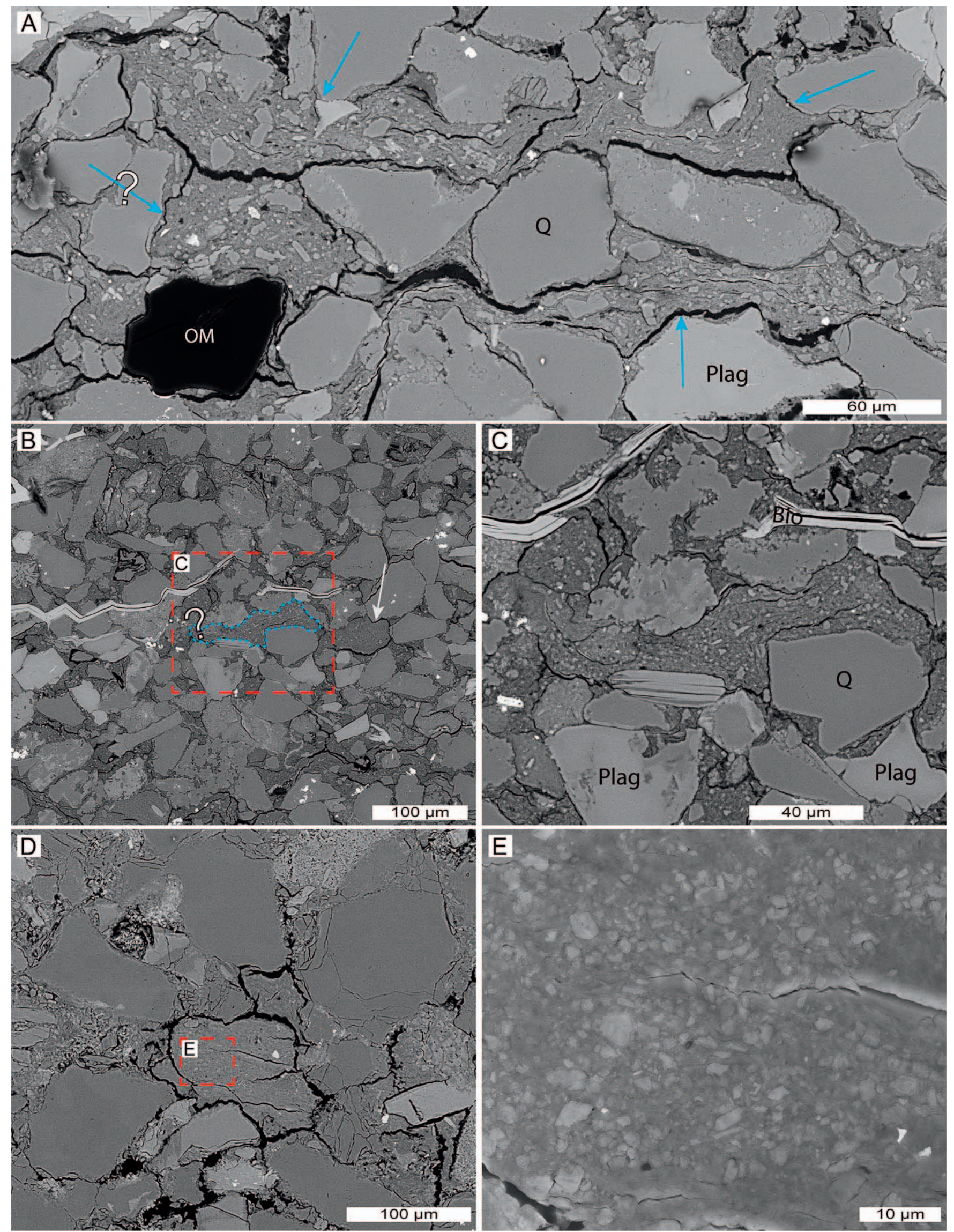


\section{Implications for Petrographic Examinations in Mudstones}

Due to the time-consuming nature of sample preparation and integrated (optical microscopy and SEM) petrographic examination, as well as the general challenges of recognizing MCPs in mudstones, the relative abundance of three distinct types of MCPs can only be semiquantified in this study (Table 4). Integrated with the general depositional model, the fine-grained matrix, which accounts for more than $50 \%$ of the Tununk Shale (Table 1), is also likely to be composed of water-rich MCPs including floccules and mud rip-up clasts. Due to their close compositional similarity and little preservation potential, the relative abundance of floccules and mud rip-up clasts cannot be quantitatively stated. Nevertheless, the prevalence of MCPs and their implication for deposition of the Tununk Shake cannot be disputed and is an aspect that has not been addressed in many prior studies of mudstone successions.

A number of previous studies of other marine shales deposited in the WIS during the Late Cretaceous have documented the common presence of fecal pellets (e.g., Hattin 1975; Sethi and Leithold 1994; Birgenheier et al. 2017). In contrast, none of the prior petrographic studies have directly documented the presence of volcanic rock fragments and shale lithics in these rocks, despite the fact that a significant amount of sediment supply for these rocks was from volcanic input and erosion of the Sevier orogenic belt and volcanic highlands.

Each type of MCP may show complex variability in petrographic composition and texture. Fecal pellets produced by other organisms in various depositional environments and/or ages can potentially differ significantly in characteristics from those described from the Tununk Shale. Marine shales deposited during other periods of high volcanic activity may also contain significant amounts of volcanic rock fragments, but higher degrees of diagenetic alteration (alteration of smectite to mixed illite-smectite and to ordered illite) may obliterate distinctive features of volcanic rock fragments in these successions (Nadeau and Reynolds 1981a, 1981b). Due to the variability of mudstone strata in general, shale lithics in various mudstone successions are also likely to exhibit a wide range of composition and texture, thus making their reliable identification a continuing challenge. Besides the three distinct types described in this study from the Tununk Shale, other types of MCPs (e.g., organo-mineralic aggregates, pedogenic aggregates) have been documented to contribute to the formation of mudstone successions in various settings to varying degrees (Rust and Nanson 1989; Wright and Marriott 2007; Macquaker et al. 2010; Dasgupta et al. 2017; Simon and Gibling 2017).

Clearly, whether a mudstone succession was formed via transport and deposition of discrete micrometer-size particles or from composite particles in the coarse silt to fine sand range implies significantly different interpretations of depositional processes and environments. For example, based on dominant mineralogy, the Tununk Shale was previously described as a hemipelagic mudstone and interpreted to have accumulated mainly through fallout from suspension (Leithold 1994; Leithold and Dean 1998). Detailed petrographic analyses in this study, however, indicate that it is more appropriate to consider the Tununk Shale as lithic muddy sandstone or sandy mudstone during its deposition. The prevalence of silt- to sandsize MCPs in the Tununk Shale points to a significant role of bottom currents in the transport and deposition of these sediments in a comparatively energetic shelf environment.

Variations in the relative amounts of different types of MCPs with contrasting mineral compositions and textures in mudstones may significantly influence how mudstone strata impact the outcome of basin modeling and geochemical and petrophysical studies of mudstone-rich successions. Some basin-analysis techniques, for example, backstripping, apply empirical porosity-depth relationships to estimate the amplitude of tectonic subsidence and sea-level change from the stratigraphic record (Steckler and Watts 1978; Miller et al. 2005). If an initial mud deposit were to consist of varying amounts of water-rich MCPs (e.g., floccules and mud rip-up clasts) as well as MCPs with much lower water contents (e.g., volcanic rock fragments and shale lithics) the deposit would undergo different degrees of compaction than conventionally assumed. Simply assuming high porosities of the initial mud deposit (80-85 vol\%; Schimmelmann et al. 1990) without prior petrographic examination may therefore result in erroneous outcomes of backstripping. Another set of techniques commonly applied in shale studies is to infer paleoclimate, oxygen content, sedimentation rate, etc., using geochemical proxies (Ross and Bustin 2009; Ver Straeten et al. 2011), with the underlying assumption that they are preserved during accumulation of mudstones. However, the wide range of the various types of MCPs revealed in this study suggests that it is entirely possible that the principal signal of the depositional environment can be mixed with or even overprinted by multiple types of MCPs that bear a different signal from their original sites of formation.

Understanding the types and abundances of MCPs in mudstones provides critical insights into the underlying causes of heterogeneity and allows for appropriate interpretation of these rocks. Results from this study highlight the benefits of careful petrographic examination by means of combined optical microscopy and SEM analysis for recognizing and characterizing MCPs of different origins in an ancient mudstone succession. More comprehensive recognition criteria for different types of MCPs, based on multiple systematic case studies, are still needed to better appreciate their relative contribution to different mudstone successions and to utilize them for improved assessments of depositional controls and processes.

\section{CONCLUSION}

Combined with sedimentary facies characteristics, detailed petrographic studies indicate that most muds in the Tununk system were probably transported in bedload in the form of mud-dominated composite particles (MCP), rather than discrete particles. Three dominant types of MCPs that can be recognized in the Tununk Shale on the basis of contrasting mineral composition and texture are (1) fecal pellets, (2) volcanic rock fragments, and (3) shale lithics. The grain size of MCPs documented in this study ranges from fine silt to medium sand size. General recognition of MCPs coarser than fine silt can be made in polished thin sections $(20-25 \mu \mathrm{m}$

FIg. 16.-Characteristics of mud rip-up clasts under the SEM. A) Same view of the multiple mud rip-up clasts shown in Figure 15A and B. For comparison, the organic matter labeled OM in Figure 16A is the same as the one labeled in Figure 15A. The mud rip-up clasts differ slightly from each other in composition and texture. All mud ripup clasts are "flattened" to some degree and are highly indented by surrounding harder grains. B) Same view of the mud rip-up clasts (outlined by blue dashed lines) and volcanic rock fragment (white arrow) shown in Figure 15C and D. The rip-up clast, as well as some biotite flakes, are deformed between harder grains. C) Closer view of the mud rip-up clasts in Part B. The boundary of this rip-up clast in the left corner is not very distinct (question mark in Part B). The long and short axes of the rip-up clast are about 120 and $34 \mu \mathrm{m}$, respectively. Assuming fully compacted to $0 \%$ porosity (based on SEM examinations) and to $30 \%$ of original thickness, the original clast contained $\sim$ $70 \mathrm{vol} \%$ water. Compared to the high initial water content of uncompacted mud deposits ( $\sim 85$ vol\%), the relatively low water content of this mud rip-up clast was produced by storm reworking of shallowly buried muds, which had become sufficiently cohesive to resist disaggregation when colliding with harder quartz or feldspar grains during transport and deposition. Q, quartz; Plag, plagioclase; Bio, biotite. D) Photomicrograph from a sample cut parallel to bedding, from the noncalcareous, silty and sandy mudstone. The MCP with irregular outline in the center is a potential mud rip-up clast. E) Closer view of the white dashed area in Part D. The common presence of fine-siltsize quartz and the irregular outline (soft during its deposition) indicates that this MCP is probably a mud rip-up clast rather than a fully compacted shale lithic. Parts A-D: backscatter electron mode; Part E: secondary electron mode. 

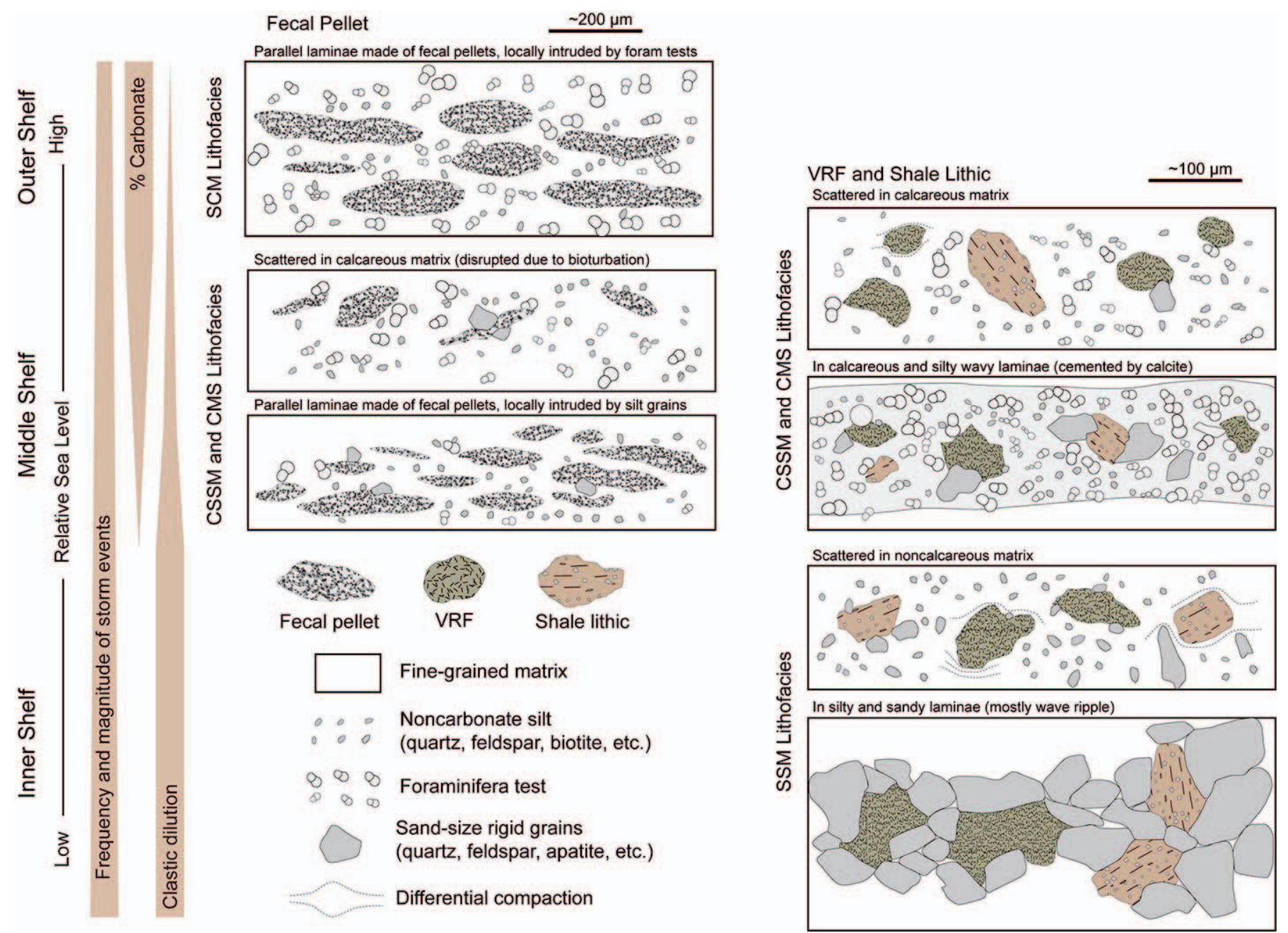

FIG. 17.- Schematic drawings that show the characteristics of three distinct types of MCPs in response to changing depositional environments of the Tununk Shale. See Table 1 caption for abbreviations of the four lithofacies packages. Fecal pellets are present only in the lower calcareous interval of the Tununk Shale. Volcanic rock fragments and shale lithics are present throughout the Tununk Shale. Volcanic rock fragments and shale lithics present in the silt-bearing, calcareous mudstone facies show the same characteristics as those in the carbonate-bearing, silty and sandy mudstone facies and carbonate-bearing, silty mudstone to muddy siltstone facies, and therefore are not depicted. Two other types of MCP, including floccules and mud rip-up clasts were probably abundant components of the fine-grained matrix of the Tununk Shale. Due to their water-rich nature, however, they are no longer discernible in the rock record under most circumstances.

thickness) using optical microscopy, whereas identification of MCP type requires SEM analysis. Ion-milled surfaces and SEM analysis are required to recognize small (fine silt size) MCPs in mudstones. In the Tununk Shale, two other types of MCP, namely floccules and mud rip-up clasts, likely were abundant components. Due to their water-rich nature, however, they can be discerned in the rock record only under fortunate circumstances and with great difficulty, and instead form what most would consider the finegrained "matrix." The compositional and textual heterogeneity observed in the Tununk Shale can be linked to changes in depositional environments and can yield important insights into the provenance of these rocks.

The question of prevalence and origin of MCPs in mudstone successions is an as-yet-undeveloped aspect of most mudstone studies, but it has potential for significant impact in the future. The recognition criteria proposed for MCP types in the Tununk Shale can serve as a template for investigating MCPs in analogous mudstone successions of similar age. However, different characteristics and dominant types of MCPs should be expected in mudstone successions deposited in different settings and ages. Results from this study reinforce the notion that detailed petrographic examination of fine-grained sedimentary rocks is an essential route to understanding their depositional history and their implications for basin analysis. Arriving at that destination will require a repertoire of case studies that span the range of depositional and tectonic settings.

\section{SUPPLEMENTAL MATERIAL}

Appendix 1 and Supplemental Figure 1 are available from JSR's Data Archive: https://www.sepm.org/pages.aspx?pageid=229.

\section{ACKNOWLEDGMENTS}

We thank Dr. Lauren Birgenheier and two anonymous reviewers, Associate Editor Dr. Sven Egenhoff, Editor Dr. Gary Hampson, and Corresponding Editor John Southard for their valuable comments and suggestions on the manuscript. Comments by Dr. Joe Macquaker on an earlier version of the manuscript are also appreciated. This research was supported by the sponsors of the Indiana University Shale Research Consortium (Anadarko, Chevron, ConocoPhillips, ExxonMobil, Shell, Statoil, Marathon, Whiting, and Wintershall). Additional support was provided through student research grants and fellowships awarded to Zhiyang Li by the Geological Society of America, SEPM (Society for 
Sedimentary Geology), American Association of Petroleum Geologists (Donald A. and Mary O'Nesky Named Grant), and the Indiana University Department of Geological Sciences (Grassman Fellowship). Many thanks to Sue Fivecoat and John Reay from the Bureau of Land Management (BLM) at Henry Mountains Field Station for their guidance and help on granting us permits for fieldwork in the study area. We also thank Bei Liu, Britt Rossman, and Matthew Leung for their assistance in the field.

\section{REFERENCES}

Allison, M.A., Lee, M.T., Ogston, A.S., And Aller, R.C., 2000, Origin of Amazon mudbanks along the northeastern coast of South America: Marine Geology, v. 163, p. $241-256$.

ARNotT, R.W., AND Southard, J.B., 1990, Exploratory flow-duct experiments on combinedflow bed configurations, and some implications for interpreting storm-event stratification: Journal of Sedimentary Petrology, v. 60, p. 211-219.

Bhattacharya, J.P., and MacEachern, J.A., 2009, Hyperpycnal rivers and prodeltaic shelves in the Cretaceous seaway of North America: Journal of Sedimentary Research, v. 79, p. 184-209.

Birgenheier, L.P., Horton, B., McCauley, A.D., Johnson, C.L., and Kennedy, A., 2017, A depositional model for offshore deposits of the lower Blue Gate Member, Mancos Shale, Uinta Basin, Utah, USA: Sedimentology, v. 64, p. 1402-1438.

BlaKey, R.C., 2014, Paleogeography and paleotectonics of the Western Interior Seaway, Jurassic-Cretaceous of North America: American Association of Petroleum Geologists, Search and Discovery Article \#30392, p. 1-72.

Cameron, K.L., And Blatt, H., 1971, Durabilities of sand size schist and "volcanic" rock fragments during fluvial transport, Elk Creek, Black Hills, South Dakota: Journal of Sedimentary Petrology, v. 41, p. 565-576.

Dasgupta, S., Ghosh, P., and Gierlowski-Kordesch, E.H., 2017, A discontinuous ephemeral stream transporting mud aggregates in a continental rift basin: the Late Triassic Maleri Formation, India: Journal of Sedimentary Research, v. 87, p. 838-865 doi: $10.2110 /$ jsr.2017.47

Decelles, P.G., 2004, Late Jurassic to Eocene evolution of the Cordilleran thrust belt and foreland basin system, western U.S.A: American Journal of Science, v. 304, p. 105-168.

Decelles, P.G., AND CoOgan, J.C., 2006, Regional structure and kinematic history of the Sevier fold-and-thrust belt, central Utah: Geological Society of America, Bulletin, v. 118 p. 841-864.

Denommee, K.C., Bentley, S.J., Harazim, D., and Macquaker, J.H.S., 2016, Hydrodynamic controls on muddy sedimentary-fabric development on the southwest Louisiana subaqueous delta: Marine Geology, v. 382, p. 162-175.

Dumas, S., Arnott, R.W.C., And Southard, J.B., 2005, Experiments on oscillatory-flow and combined-flow bed forms: implications for interpreting parts of the shallow-marine sedimentary record: Journal of Sedimentary Research, v. 75, p. 501-513.

Fisher, R.V., AND SCHMincKe, H.-U., 1984, Alteration of volcanic glass, in Fisher, R.V., and Schmincke, H.U., eds., Pyroclastic Rocks: Berlin, Springer, p. 312-345.

HAQ, B.U., 2014, Cretaceous eustasy revisited: Global and Planetary Change, v. 113, p. 44 58.

Harazim, D., and McIlroy, D., 2015, Mud-rich density-driven flows along an Early Ordovician storm-dominated shoreline: Implications for shallow-marine facies models Journal of Sedimentary Research, v. 85, p. 509-528. doi:10.2110/jsr.2015.38

Hattin, D.E., 1975, Petrology and origin of fecal pellets in upper Cretaceous strata of Kansas and Saskatchewan: Journal of Sedimentary Petrology, v. 45, p. 686-696.

HAY, W.W., 2008, Evolving ideas about the Cretaceous climate and ocean circulation: Cretaceous Research, v. 29, p. 725-753.

Honso, S., 1976, Coccoliths: production, transportation and sedimentation: Marine Micropaleontology, v. 1, p. 65-79.

Honso, S., 1982, Seasonality and interaction of biogenic and lithogenic particulate flux at the Panama Basin: Science, v. 218, p. 883-884.

KaUfFMAn, E.G., 1977, Geological and biological overview: Western Interior Cretaceous basin: Mountain Geologist, v. 14, p. 75-99.

Kauffman, E.G., 1985, Cretaceous evolution of the Western Interior Basin of the United States, in Pratt, L.M., Kauffman, E.G., and Zelt, F.B., eds., Fine-grained deposits and biofacies of the Cretaceous Western Interior seaway: evidence of cyclic sedimentary processes: SEPM, Field Trip Guidebook, no. 4, p. iv-xiii.

Kauffman, E.G., and Caldwell, W.G.E., 1993, The Western Interior Basin in space and time, in Caldwell, W.G.E., and Kauffman, E.G., eds., Evolution of the Western Interior basin: Geological Association of Canada, Special Paper 39, p. 1-30.

Knapp, L.J., McMillan, J.M., and Harris, N.B., 2017, A depositional model for organicrich Duvernay Formation mudstones: Sedimentary Geology, v. 347, p. 160-182.

KRANCK, K., 1975, Sediment deposition from flocculated suspensions: Sedimentology, v. 22, p. 111-123.

Laycock, D.P., Pedersen, P.K., Montgomery, B.C., And Spencer, R.J., 2017, Identification, characterization, and statistical analysis of mudstone aggregate clasts, Cretaceous Carlile Formation, Central Alberta, Canada: Marine and Petroleum Geology, v. 84, p. 49-63.

Lazar, O.R., Bohacs, K.M., Macquaker, J.H.S., Schieber, J., and Demko, T.M., 2015, Capturing key attributes of fine-grained sedimentary rocks in outcrops, cores, and thin sections: nomenclature and description guidelines: Journal of Sedimentary Research, v. 85, p. 230-246. doi:10.2110/jsr.2015.11

Leithold, E.L., 1994, Stratigraphical architecture at the muddy margin of the Cretaceous Western Interior Seaway, southern Utah: Sedimentology, v. 41, p. 521-542.

Leithold, E.L., and Dean, W.E., 1998, Depositional processes and carbon burial on a Turonian prodelta at the margin of the Western Interior Seaway: SEPM, Concepts in Sedimentology and Paleontology, v. 6, p. 189-200.

Li, Z., Bhattacharya, J., and Schieber, J., 2015, Evaluating along-strike variation using thin-bedded facies analysis, Upper Cretaceous Ferron Notom Delta, Utah: Sedimentology, v. 62, p. 2060-2089.

Li, Z., AND Schieber, J., 2018, Detailed facies analysis of the Upper Cretaceous Tununk Shale Member, Henry Mountains Region, Utah: implications for mudstone depositional models in epicontinental seas: Sedimentary Geology, v. 364, p. 141-159.

Lick, W., HuAng, H., AND JePSEN, R., 1993, Flocculation of fine-grained sediments due to differential settling: Journal of Geophysical Research, Oceans, v. 98, p. 10279-10288.

LIVACCARI, R.F., 1991, Role of crustal thickening and extensional collapse in the tectonic evolution of the Sevier-Laramide orogeny, western United States: Geology, v. 19, p. $1104-1107$

LoBZA, V., AND SCHIEBER, J., 1999, Biogenic sedimentary structures produced by worms in soupy, soft muds: observations from the Chattanooga Shale (Upper Devonian) and experiments: Journal of Sedimentary Research, v. 69, p. 1041-1049.

MacquaKer, J.H.S., AND BoHacs, K.M., 2007, On the accumulation of mud: Science, v 318, p. 1734

MacquaKer, J.H.S., And GaWthorpe, R.L., 1993, Mudstone lithofacies in the Kimmeridge Clay Formation, Wessex Basin, southern England; implications for the origin and controls of the distribution of mudstones: Journal of Sedimentary Research, v. 63, p. $1129-1143$.

Macquaker, J.H.S., Keller, M.A., and Davies, S.J., 2010, Algal blooms and "marine snow": mechanisms that enhance preservation of organic carbon in ancient fine-grained sediments: Journal of Sedimentary Research, v. 80, p. 934-942.

Miller, K.G., Kominz, M.A., Browning, J.V., Wright, J.D., Mountain, G.S., Katz, M.E., Sugarman, P.J., Cramer, B.S., Christie-Blick, N., and Pekar, S.F., 2005, The Phanerozoic record of global sea-level change: Science, v. 310, p. 1293-1298.

Minoura, K., AND OsaKa, Y., 1992, Sediments and sedimentary processes in Mutsu Bay, Japan: pelletization as the most important mode in depositing argillaceous sediments: Marine Geology, v. 103, p. 487-502.

Nadeau, P.H., and ReYnolds, R.C., 1981a, Burial and contact metamorphism in the Mancos Shale: Clays and Clay Minerals, v. 29, p. 249-259.

Nadeau, P.H., And Reynolds, R.C., 1981b, Volcanic components in pelitic sediments: Nature, v. 294 , p. $72-74$.

Nittrouer, C.A., Kuehl, S.A., Demaster, D.J., and Kowsmann, R.O., 1986, The deltaic nature of Amazon shelf sedimentation: Geological Society of America, Bulletin, v. 97, p. $444-458$

Nowell, A.R.M., Jumars, P.A., And Eckman, J.E., 1981, Effects of biological activity on the entrainment of marine sediments: Marine Geology, v. 42, p. 133-153.

Oenmig, R., 1993, Entrainment of planktonic foraminifera: effect of bulk density: Sedimentology, v. 40, p. $869-877$

OgG, J.G., Hinnov, L.A., And Huang, C., 2012, Chapter 27, Cretaceous, in Gradstein, F.M., Ogg, J.G., Schmitz, M.D., and Ogg, G.M., eds., The Geologic Time Scale: Elsevier, p. 793-853.

Peterson, F., Ryder, R.T., and Law, B.E., 1980, Stratigraphy, sedimentology, and regional relationships of the Cretaceous System in the Henry Mountains region, Utah, in Picard, M.D., ed., Henry Mountains Symposium: Utah Geological Association, Publication 8, p. 151-170.

Plint, A.G., 2014, Mud dispersal across a Cretaceous prodelta: storm-generated, waveenhanced sediment gravity flows inferred from mudstone microtexture and microfacies: Sedimentology, v. 61, p. 609-647.

Plint, A.G., Macquaker, J.H., And Varban, B.L., 2012, Bedload transport of mud across a wide, storm-influenced ramp: Cenomanian-Turonian Kaskapau Formation, Western Canada Foreland Basin: Journal of Sedimentary Research, v. 82, p. 801-822.

Potter, P.E., Maynard, J.B., And Depetris, P.J., 2005, Mud and Mudstones: Introduction and Overview: Berlin, Springer-Verlag, $297 \mathrm{p}$

Rine, J.M., AND GinsbuRG, R.N., 1985, Depositional facies of a mud shoreface in Suriname, South America: a mud analogue to sandy, shallow-marine deposits: Journal of Sedimentary Petrology, v. 55, p. 633-652.

Ross, D.J.K., AND Bustin, R.M., 2009, Investigating the use of sedimentary geochemical proxies for paleoenvironment interpretation of thermally mature organic-rich strata: examples from the Devonian-Mississippian shales, Western Canadian Sedimentary Basin: Chemical Geology, v. 260, p. 1-19.

Rust, B.R., AND NANSON, G.C., 1989, Bedload transport of mud as pedogenic aggregates in modern and ancient rivers: Sedimentology, v. 36, p. 291-306.

Ryer, T., AND Lovekin, J., 1986, The Upper Cretaceous Vernal Delta of Utah: depositional or paleotectonic feature, in Peterson, J.A., ed., Paleotectonics and sedimentation in the Rocky Mountain Region: American Association of Petroleum Geologists, Memoir 41, p. 497-509.

Sageman, B.B., And ARThur, M.A., 1994, Early Turonian paleogeographic/paleobathymetric map, Western Interior, US, in Caputo, M.V., Peterson, J.A., and Franczyk, K.J., eds., Mesozoic Systems of the Rocky Mountain Region, USA: SEPM, Rocky Mountain Section, Denver, Colorado, p. 457-470. 
SCHIEBER, J., 1999, Distribution and deposition of mudstone facies in the Upper Devonian Sonyea Group of New York: Journal of Sedimentary Research, v. 69, p. 909-925.

SCHIEBER, J., 2011, Reverse engineering mother nature: shale sedimentology from an experimental perspective: Sedimentary Geology, v. 238, p. 1-22.

SchiEBER, J., 2013, SEM observations on ion-milled samples of Devonian black shales from Indiana and New York: the petrographic context of multiple pore types, in Camp, W.K., Diaz, E., and Wawak, B., eds., Electron Microscopy of Shale Hydrocarbon Reservoirs: American Association of Petroleum Geologists, Memoir 102, p. 153-171.

Schieber, J., 2016a, Mud re-distribution in epicontinental basins, exploring likely processes: Marine and Petroleum Geology, v. 71, p. 119-133.

SCHIEBER, J., 2016b, Experimental testing of the transport-durability of shale lithics and its implications for interpreting the rock record: Sedimentary Geology, p. 162-169.

Schieber, J., AND Bennett, R., 2013, Bedload transport of mud across a wide, storminfluenced ramp: Cenomanian-Turonian Kaskapau Formation, western Canada foreland basin-Discussion: Journal of Sedimentary Research, v. 83, p. 1198-1199. doi:10.2110/ jsr.2013.87

SchieBER, J., AND Southard, J.B., 2009, Bedload transport of mud by floccule ripples: direct observation of ripple migration processes and their implications: Geology, v. 37, p. 483 486.

Schieber, J., Southard, J., and Thaisen, K., 2007, Accretion of mudstone beds from migrating floccule ripples: Science, v. 318, p. 1760-1763.

Schieber, J., Southard, J.B., And Schimmelmann, A., 2010, Lenticular shale fabrics resulting from intermittent erosion of water-rich muds: interpreting the rock record in the light of recent flume experiments: Journal of Sedimentary Research, v. 80, p. 119-128.

Schieber, J., Southard, J.B., Kissling, P., Rossman, B., and Ginsburg, R., 2013 Experimental deposition of carbonate mud from moving suspensions: importance of flocculation and implications for modern and ancient carbonate mud deposition: Journal of Sedimentary Research, v. 83, p. 1026-1032. doi:10.2110/jsr.2013.77

Schimmelmann, A., Lange, C.B., And Berger, W.H., 1990, Climatically controlled marker layers in Santa Barbara Basin sediments and fine-scale core-to-core correlation: Limnology and Oceanography, v. 35, p. 165-173.

Sethi, P.S., And Leithold, E.L., 1994, Climatic cyclicity and terrigenous sediment influx to the early Turonian Greenhorn Sea, southern Utah: Journal of Sedimentary Research, v. 64 , p. 26-39.

Shchepetkina, A., Gingras, M.K., and Pemberton, S.G., 2018, Modern observations of floccule ripples: Petitcodiac River estuary, New Brunswick, Canada: Sedimentology, v 65 , p. $582-596$.

Simon, S.S.T., AND Gibling, M.R., 2017, Pedogenic mud aggregates preserved in a finegrained meandering channel in the Lower Permian Clear Fork Formation, north-centra Texas, U.S.A: Journal of Sedimentary Research, v. 87, p. 230-252. doi:10.2110/jsr.201 7.12

Steckler, M.S., And WatTs, A.B., 1978, Subsidence of the Atlantic-type continental margin off New York: Earth and Planetary Science Letters, v. 41, p. 1-13.
Traykovski, P., GeYer, W.R., Irish, J.D., And Lynch, J.F., 2000, The role of wave-induced density-driven fluid mud flows for cross-shelf transport on the Eel River continental shelf: Continental Shelf Research, v. 20, p. 2113-2140.

Ulmer-Scholle, D.S., Scholle, P.A., Schieber, J., And Raine, R.J., 2015, A Color Guide to the Petrography of Sandstones, Siltstones, Shales, and Associated Rocks, American Association of Petroleum Geologists, 524 p.

Ver Straeten, C.A., Brett, C.E., and Sageman, B.B., 2011, Mudrock sequence stratigraphy: a multi-proxy (sedimentological, paleobiological and geochemical) approach, Devonian Appalachian Basin: Palaeogeography, Palaeoclimatology, Palaeoecology, v. 304, p. 54-73.

WeIMER, R.J., 1984, Relation of unconformities, tectonics, and sea-level changes, Cretaceous of Western Interior, U.S.A, in Schlee, J.S., ed., Interregional Unconformities and Hydrocarbon Accumulation: American Association of Petroleum Geologists, Memoir 36, p. 7-35

Wilson, R.D., AND Schieber, J., 2014, Muddy prodeltaic hyperpycnites in the Lower Genesee Group of central New York, USA: implications for mud transport in epicontinental seas: Journal of Sedimentary Research, v. 84, p. 866-874. doi:10.2110/ jsr.2014.70

WILSON, R.D., AND SCHIEBER, J., 2015, Sedimentary facies and depositional environment of the Middle Devonian Geneseo Formation of New York, U.S.A.: Journal of Sedimentary Research, v. 85, p. 1393-1415. doi:10.2110/jsr.2015.88

Wright, L.D., Wiseman, W.J., Bornhold, B.D., Prior, D.B., Suhayda, J.N., Keller, G.H., YANG, Z.S., AND FAN, Y.B., 1988, Marine dispersal and deposition of Yellow River silts by gravity-driven underflows: Nature, v. 332, p. 629-632.

Wright, V.P., AND MarriotT, S.B., 2007, The dangers of taking mud for granted: lessons from Lower Old Red Sandstone dryland river systems of South Wales: Sedimentary Geology, v. 195, p. 91-100.

YAWAR, Z., AND Schieber, J., 2017, On the origin of silt laminae in laminated shales: Sedimentary Geology, v. 360, p. 22-34.

YonkeE, W.A., AND WeIL, A.B., 2015, Tectonic evolution of the Sevier and Laramide belts within the North American Cordillera orogenic system: Earth-Science Reviews, v. 150, p. $531-593$.

Zelt, F.B., 1985, Natural gamma-ray spectrometry, lithofacies, and depositional environments of selected upper Cretaceous marine mudrocks, western United States, including Tropic Shale and Tununk Member of Mancos Shale [Ph.D. Thesis]: Princeton, New Jersey, Princeton University, 372 p.

Zimmerle, W., 1993, On the lithology and provenance of the Rupelian Boom Clay in northern Belgium, a volcaniclastic deposit: Société Belge de Géologie, Bulletin, v. 102, p. $91-103$.

Zimmerle, W., 1998, Petrography of Boom Clay from the Rupelian type locality, northern Belgium, in Schieber, J., and Zimmerle, W., eds., Shales and Mudstones: Stuttgart, E. Schweizerbart'sche, p. 13-33.

Received 27 February 2018; accepted 9 October 2018 